Summer 2013

\title{
Chinese Women in Legal Education
}

Xiaonan Liu

China University of Political Science and Law

Follow this and additional works at: https://www.repository.law.indiana.edu/ijgls

Part of the International Law Commons, Law and Gender Commons, Law and Society Commons, Legal Education Commons, and the Legal Profession Commons

\section{Recommended Citation}

Liu, Xiaonan (2013) "Chinese Women in Legal Education," Indiana Journal of Global Legal Studies: Vol. 20 : Iss. 2 , Article 25.

Available at: https://www.repository.law.indiana.edu/ijgls/vol20/iss2/25

This Symposium is brought to you for free and open access by the Law School Journals at Digital Repository @ Maurer Law. It has been accepted for inclusion in Indiana Journal of Global Legal Studies by an authorized editor of Digital Repository @ Maurer Law. For more information, please contact rvaughan@indiana.edu.

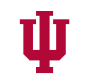

JEROME HALL LAW LIBRARY

$$
\text { INDIANA UNIVERSITY }
$$

Maurer School of Law
Bloomington 


\title{
Chinese Women in Legal Education
}

\author{
XIAONAN LIU*
}

\begin{abstract}
This paper examines the history and development of women entering legal education in China. Based on a survey, interviews, and archival research, this paper attempts to analyze Chinese women's current status in legal education and reaches the conclusion that although women have made significant gains in legal education, they are still facing gender discrimination and bias in the legal sector. The paper also looks into the reasons why women have in the past belonged to "the other" in the legal area, and whether there is any conflict between "legal characteristics" and "feminine characteristics." It attempts to break the constraint caused by dualism and gender essentialism.
\end{abstract}

\section{The History of ChINESE WOMEN'S ENTRY INTO LEgAL EdUCATION}

Over thousands of years of Chinese history, Chinese women had a subordinate social status to men not only in the political and economic arenas, but also within the family. This has been attributed to the longstanding historical influence of Confucianism, which held that men were naturally superior to women. Accordingly, women were generally excluded from the formal education system. Not until the modern era, with the development of feminism as well as the introduction of western democratic ideas, did the Chinese higher education system begin to relax its prohibition against female enrollment and allow women to have access to schools. ${ }^{1}$ In 1919, eight years after the 1911 revolution that overthrew China's last royal dynasty, Beijing Women's Normal College was established, which upgraded to National Women's Normal University in 1924, becoming the first national college for women Law.

* Xiaonan Liu is an Associate Professor at China University of Political Science and

1. AN SHUFEN (安树芬), ZHONG GUO NÜ XING GAO DENG JIAO YU DE LI SHI YU XIAN ZHUANG YAN JIU (中国女性高等教育的历史与现状研究) [CHINESE HIGHER EDUCATION FOR WOMEN PAST AND PRESENT] 116 (2002).

Indiana Journal of Global Legal Studies Vol. 20, Issue 2 (2013)

(C) Indiana University Maurer School of Law 
established by the Chinese Republican government. ${ }^{2}$ In 1922 , the newly-implemented education system called "Renxu Xuezhi 壬戌学制" (The 1922 Institutionalization of Education Act) legally affirmed, for the first time, that women's rights to receive an education should be equal to those of men at every level of schooling; it also affirmed the existence of higher education institutions for women. ${ }^{3}$ In principle, the 1922 education act gave a green light for women to enroll in any type of school or college, not only the independent women's colleges. However, because the concept of male-female social equality was so new at that time, and broader restrictions on women's activities remained prevalent, discrimination in education was still widespread. A large number of universities were not accessible to women before the 1930s. As a result, during 1922-1923, for example, female college students only accounted for 2.54 percent of the total number of college students. Even in 1928-1929, female college students only accounted for 8.42 percent of all students. ${ }^{4}$ In short, opportunities for women to receive higher education were extremely limited during that period.

The establishment of the law department at Beiyang University in Tianjin in October 1895 marked the beginning of modern higher legal education in China. ${ }^{5}$ However, at that time, only male students could be enrolled. Soon after the Revolution of 1911, an advertisement published in Shanghai's Minli newspaper announced that a women's college of law and politics would be founded and prospective female law students were being sought. ${ }^{6}$ Unfortunately, women in Shanghai showed little interest in this advertisement, and the women's college of law closed quickly. ${ }^{7}$ In the 1920s, Shanghai University of Law and Politics and Shanghai University of Law both opened their doors to women, but the number of enrolled female students was very low. ${ }^{8}$ Shi Liang, who later became the first minister of justice in the People's Republic of China, recalled that when she graduated from Shanghai University of Law in 1927, there

2. JIANG LI-JING (姜丽静), From Periphery to Center: Approaching Beijing Women's Normal College, J. HIGHER EDUC. Nov. 2009, at 80.

3. AN SHUFEN (安树芬), ZHONGGUO NÜ XING GAO DENG JIAO YU DE LI SHI YU XIAN ZHUANG YAN JIU (中国女性高等教育的历史与现状研究) [CHINESE HIGHER EDUCATION FOR WOMEN PAST AND PRESENT] 116 (2002).

4. Id. at 121 .

5. WANG JIAN (王健), ZHONGGUO JIN DAI DE FA LÜ JIAO YU (中国伒代的法律誵) [LEGAL EDUCATION IN MODERN CHINA] 154 (2001).

6. Sun Huei-min (孙慗敏), MIN Guo ShI QI Shang HaI De NÜ LÜ SHI (民国时期上海的女律师1927-1949) [Women Lawyers in Republican Shanghai (1927-1949)], 14 JIN DAI ZHONGGUO FU NÜ SHI YAN JIU (近代中国妇女史确) [RES. ON WOMEN MOD. CHINESE HIST.] 51, 56 (2006).

7. Id. at 57 .

8. Id. at 59 . 
were only three female graduates in the whole university. ${ }^{9}$ According to a registration book of graduates of the Shanghai University of Law and Politics published in 1933, a total of 444 students graduated from the departments of law and politics between 1927 and 1932, but there were only eighteen female graduates among them. ${ }^{10}$ The registration books (1931-1948) of the Shanghai University of Law show that among the 747 college graduates from the department of law, only 8 percent, or 62 graduates, were female. ${ }^{11}$ The most prestigious law school of that period, at Soochow University, was established in 1915, but did not admit women until 1928. Three years later the first group of female students graduated from the law school. In the academic year of 1933-1934, there were twenty-eight female students at Soochow Law School, almost 10 percent of the student body. ${ }^{12}$

9. Id.

10. Id.

11. Id. at 60 .

12. Yang Dachun (杨大春), ZHONG GUO YING MEI FA XUE JIAO YU DE YAO LAN (中国英美法学教育的罍篮) [The Cradle of British and American Law Education in China], DONG WU FA XUE (东吴法学) [SOOCHOW L.J.] 18 (2003). 
Table 1. National Statistics of the Number of Colleges and Students in 1923

\begin{tabular}{|c|c|c|c|c|c|c|}
\hline \multirow{2}{*}{$\begin{array}{l}\text { Types of } \\
\text { Universities/ } \\
\text { Colleges }\end{array}$} & \multicolumn{3}{|c|}{ Number of Colleges } & \multicolumn{3}{|c|}{ Number of Students } \\
\hline & Male & Female & $\begin{array}{l}\text { Sub } \\
\text { Total }\end{array}$ & Male & Female & $\begin{array}{l}\text { Sub } \\
\text { Total }\end{array}$ \\
\hline Universities & 34 & 1 & 35 & 12,692 & 431 & 13,123 \\
\hline $\begin{array}{l}\text { Teacher's } \\
\text { Colleges }\end{array}$ & 7 & 1 & 8 & 2,809 & 284 & 3,093 \\
\hline $\begin{array}{l}\text { Agriculture } \\
\text { Colleges }\end{array}$ & 7 & 0 & 7 & 1,271 & 0 & 1,271 \\
\hline $\begin{array}{l}\text { Engineering } \\
\text { Colleges }\end{array}$ & 13 & 0 & 13 & 2,018 & 8 & 2,026 \\
\hline $\begin{array}{l}\text { Business } \\
\text { Colleges }\end{array}$ & 8 & 0 & 8 & 1,887 & 3 & 1,890 \\
\hline $\begin{array}{l}\text { Medical } \\
\text { Colleges }\end{array}$ & 7 & 0 & 7 & 815 & 17 & 832 \\
\hline $\begin{array}{l}\text { Law } \\
\text { Colleges }\end{array}$ & 33 & 0 & 33 & 10,851 & 13 & 10,864 \\
\hline Others & 14 & 0 & 14 & 1,650 & 131 & 1,781 \\
\hline Total & 123 & 2 & 125 & 33,993 & 887 & 34,880 \\
\hline
\end{tabular}

Source: Yu Qingtang (前庆棠), San shi wu nian lai zhong guo zhi nü zi jiao yu（三十五年来中国之女子教育） [Chinese women's Education in past 35 years], Zhong guo fu nü shi lun wen ji (中国妇女史论文集第1辑) [paper collection of the history of chinese Women] li you ning \& zhang yu fa (李又宁、张玉法), 364 (1981).

Table 2. National Statistics on Postgraduate Education in 1947

\begin{tabular}{llllll}
\hline & Total & Arts & Law & Education & $\begin{array}{l}\text { Science and } \\
\text { Engineering }\end{array}$ \\
\hline Male & 366 & 87 & 91 & 26 & 162 \\
Female & 58 & 19 & 7 & 1 & 31 \\
\hline
\end{tabular}

Source: An Shufen (安树芬), Zhongguo nü xing gao deng jiao yu de li shi yu xian zhuang yan jiu (中国女性高等教育的历史与现状研究) [Chinese Higher Education for Women Past and Present] 100 (2002).

No female teachers existed at law schools in China before World War II, but beginning in the late 1940s, law schools began to hire their 
female graduates to join their faculties. ${ }^{13}$ In 1947, there were five women on the faculty of Soochow Law School, four of whom were Soochow Law graduates, but only two of whom taught law. ${ }^{14}$ These two women were Cecilia Sieu-ling Zung (class of 1934) and Grace M.T. Tan (class of 1937), both of whom had also obtained S.J.D. degrees from New York University (Tan in 1939, Zung in 1942). ${ }^{15}$

\section{The CurRent Gender Composition of Legal EduCATION IN CHINA}

The Chinese Constitution and other laws thoroughly affirm that women have equal rights in culture, education, economic life, and politics. ${ }^{16}$ Not only the number of women in higher education, but also the level of the academic degrees earned by women, have risen tremendously in China since 1949.17 With the increase in the number of female students, the number of female professors has also increased. ${ }^{18}$ However, the only available statistics concerning student and faculty gender in China are for higher education as a whole, and not for legal education specifically; Chinese law schools generally do not release data about the gender of their own faculty and students. As a result, in the following section, I have used the gender statistics for higher education as a whole and data from a limited number of law schools to demonstrate the gender composition of legal education.

13. Alison W. Conner, Training China's Early Modern Lawyers: Soochow University Law School, 8 J. CHINESE L. 1, 24 (1994).

14. Id.

15. Id.

16. Article 4 of the Compulsory Education Law of the People's Republic of China states: "All school-age children and adolescents of the nationality of the People's Republic of China shall, in accordance with law, enjoy the equal right, and fulfill the obligation, to receive compulsory education, regardless of sex, ethnic status or race, family financial conditions, religious belief, etc." ZHONG HUA REN MIN GONG HE GUO YI WU JiAO YU FA (中华人民共和国义务教育法) [Compulsory Education Law of the People's Republic of China] (promulgated by the Standing Comm. Nat'l People's Cong., June 29, 2006, effective Sept. 1 , 2006), available at http://www.china.org.cn/china/LegislationsForm20012010/2011-02/15/content_21925515.htm.

17. In 1949, female students in higher education only accounted for $19.77 \%$ of students, a figure that increased to $50.86 \%$ in 2010 . In 1963, female graduate students only accounted for $16 \%$ of all graduate students, a figure that increased to $47.86 \%$ in 2010 . See Zhongguo Jiaoyu Nianjian 1949-1981 (中国教育年签 1949-1981) [China Education Yearbook 1949-1981] 974 (1981); Zhongguo Jiaoyu Tongji Nianjian 2010 (中国教育统计年鉴 2010) [Educational Statistics Yearbook of China 2010] 5 (2010).

18. In 1951, full-time female faculty in higher education intuitions only accounted for $10.98 \%$, a figure that increased to $45.62 \%$ in 2008. See Zhongguo Jiaoyu Nianjian 1949-1981 (中国教育年鉴 1949-1981), supra note 17; Zhongguo Jiaoyu Nianjian 2009 (中国教育年篮 2009) [China Education Yearbook 2009] 108 (2009). 


\section{A. Female Students in Legal Education}

After the Cultural Revolution, China resumed the university entrance examination in 1977.19 Since then, female students have flourished in higher education and the percentage of female students in the student body has grown steadily year-by-year. The percentage of female students receiving various educational degrees has stayed at a relatively high level. In 1980, the female students in higher education accounted for 23.44 percent of students, ${ }^{20}$ a figure that increased to 50.86 percent in $2010 .{ }^{21}$ This figure reflects a historic all-time high percentage of female students in Chinese higher education. In 1980, female graduate students accounted for 11.8 percent of all graduate students in China.22 In 2010, female Ph.D candidates accounted for 35.48 percent of all $\mathrm{Ph} . \mathrm{D}$ candidates and 50.36 percent of the total master's degree candidate pool. ${ }^{23}$

19. Hubei Institute of Finance and Economics Law Department resumed classes in 1977; Southwest College of Political Science and Law, Beijing College of Political Science and Law, East China College of Political Science and Law, Northwest College of Political Science and Law, and Renmin University Law Department resumed classes in 1978 and 1979.

20. CHINA EDUCATION YEARBOOK 1949-1981, supra note 17, at 974.

21. ZHONGGUO JIAOYU TONG JI NIANJIAN 2010 (中国教育统计年鉴 2010) [EDUCATIONAL STATISTICS YEARBOOK OF CHINA 2010] 5 (2010).

22. ChINA EDUCATION YeARBOOK 1949-1981, supra note 17, at 974.

23. Comm. On the Elimination of Discrimination Against Women, China 7th and 8th Combined Reports on the Convention on the Elimination of All Forms of Discrimination Against Women, U.N. Doc. CEDAW/C/CHN/7-8 (Apr. 23, 2012). 
Table 3. The Number and Percentage of Female Students in China's Higher Education Institutions

\begin{tabular}{|l|l|l|l|l|l|l|l|}
\hline Year & $1980^{\mathrm{a}}$ & $1984^{\mathrm{b}}$ & $1990^{\mathrm{c}}$ & $1995^{\mathrm{d}}$ & $2000^{\mathrm{e}}$ & $2005^{\mathrm{f}}$ & $2010 \mathrm{~s}$ \\
\hline $\begin{array}{c}\text { Number of } \\
\text { female } \\
\text { students }\end{array}$ & 268,137 & 399,980 & 695,100 & $1,029,000$ & $2,278,900$ & $7,353,200$ & $11,350,981$ \\
\hline Percentage & $23.44 \%$ & $28.6 \%$ & $33.7 \%$ & $35.4 \%$ & $40.98 \%$ & $47.08 \%$ & $50.86 \%$ \\
\hline
\end{tabular}

a Zhongguo Jiaoyu Nianjian 1949-1981 (中国教育年鉴 1949-1981) [China Education Yearbook 1949-1981] 974 (1981).

b Zhongguo Jiaoyu Nianjian 1982-1984 (中国教育年鉴 1982-1984) [China Education Yearbook 1982-1984] 62 (1984) (No data available for the years 1985-1986).

c Zhongguo Jiaoyu Nianjian 1991 (中国教育年鉴 1991) [China Education Yearbook 1991] 96 (1991).

d Zhongguo Jiaoyu Nianjian 1996 (中国教育年鉴 1996) [China Education Yearbook 1996] 118 (1996).

e Zhongguo Jiaoyu Nianjian 2001 (中国教育年鉴 2001) [China Education Yearbook 2001] 79 (2001).

f Zhongguo Jiaoyu Nianjian 2006 (中国教育年鉴 2006) [China Education Yearbook 2006] 121 (2006).

g Zhongguo Jiaoyu Tongji Nianjian 2010 (中国教育统计年鉴 2010) [Educational Statistics Yearbook of China 2010] 5 (2010). 
Table 4. Female Students in Higher Education in 2010

\begin{tabular}{|l|c|c|c|c|}
\hline & $\begin{array}{l}\text { Total } \\
\text { Students }\end{array}$ & Males & Females & $\begin{array}{l}\text { Percentage } \\
\text { that are } \\
\text { Female }\end{array}$ \\
\hline $\begin{array}{l}\text { 1. Graduate } \\
\text { students }\end{array}$ & $1,538,416$ & 802,186 & 736,230 & 47.86 \\
\hline - Ph.D & 258,950 & 167,063 & 91,887 & 35.48 \\
\hline $\begin{array}{l}\text { - Master's } \\
\text { degree }\end{array}$ & $1,279,466$ & 635,123 & 644,343 & 50.36 \\
\hline $\begin{array}{l}\text { 2. Ordinary } \\
\text { undergraduate }\end{array}$ & $22,317,929$ & $10,966,948$ & $11,350,981$ & 50.86 \\
\hline $\begin{array}{l}\text { - Bachelor's } \\
\text { degree }\end{array}$ & $12,656,132$ & $6,369,152$ & $6,286,980$ & 49.68 \\
\hline $\begin{array}{l}\text { - Vocational } \\
\text { training }\end{array}$ & $9,661,797$ & $4,597,796$ & $5,064,001$ & 52.41 \\
\hline $\begin{array}{l}3 . \text { Adult } \\
\text { education }\end{array}$ & $5,360,388$ & $2,512,717$ & $2,847,671$ & 53.12 \\
\hline - Undergraduate & $2,250,457$ & $1,014,973$ & $1,235,484$ & 54.90 \\
\hline $\begin{array}{l}\text { - Vocational } \\
\text { training }\end{array}$ & $3,109,931$ & $1,497,744$ & $1,612,187$ & 51.84 \\
\hline $\begin{array}{l}4 . \text { Other kinds } \\
\text { of formal higher } \\
\text { education }\end{array}$ & - & - & - & - \\
\hline $\begin{array}{l}\text { - Master's and } \\
\text { PhD students } \\
\text { with full-time } \\
\text { employment }\end{array}$ & 420,294 & 266,386 & 153,908 & 36.62 \\
\hline $\begin{array}{l}\text { - Online } \\
\text { (e-learning) } \\
\text { undergraduate } \\
\text { students }\end{array}$ & $4,531,443$ & $2,348,070$ & $2,183,373$ & 48.18 \\
\hline $\begin{array}{c}\text { - Bachelor's } \\
\text { degree }\end{array}$ & $1,640,403$ & 807,811 & 832,592 & 50.76 \\
\hline $\begin{array}{l}\text { - Vocational } \\
\text { training }\end{array}$ & $2,891,040$ & $1,540,259$ & $1,350,781$ & 46.72 \\
\hline Source: & & & & \\
\hline
\end{tabular}

Source: Comm. On the Elimination of Discrimination Against Women, China 7th and 8th Combined Reports on the Convention on the 
Elimination of All Forms of Discrimination Against Women, U.N. Doc. CEDAW/C/CHN/7-8 (Apr. 23, 2012).

Following the trend in higher education generally, Chinese women have occupied a growing number of seats at law schools. Although we do not have official statistical data showing the number of women in law schools nationwide, some research indicates that the percentage of female law students is higher than that of male students in many law schools. For example, at Peking University Law School, women accounted for 40.2 percent of the total students from 1978 to 1998 , and 61.3 percent from 2000 to $2005 .^{24}$ Zheng Xiaomin, the deputy secretary of the Communist Party at Renmin University's School of Law, has reported that in recent years, female undergraduate law students outnumber male undergraduates. ${ }^{25}$ According to Yang Tingting, an instructor at the Law School of the China University of Political Science and Law, the gender ratio of newly-enrolled law students in 2009 was two men for every three women, which means that female students accounted for 60 percent of the total. ${ }^{26}$ According to Professor $\mathrm{Xu}$ Chongli, the dean of Xiamen University Law School, two out of three undergraduate law students at his school are female, as are three out of four masters-level law students. ${ }^{27}$

An important reason for this phenomenon is that China categorizes law among the arts. ${ }^{28}$ It remains widely believed in China that women are not suited to study the sciences and engineering, but are suited to study the arts. ${ }^{29}$ Female students account for the majority of students in liberal arts classes in Chinese high schools, and the number of female applicants to law schools exceeds the number of males. For example, among the new students of Beijing University in 2000, 72 percent were women students in the major of literature; 61 percent were women students in history; 61 percent were women students in law; 60 percent were women students in foreign language; 85.6 percent were men

24. Liu Yunshan \& Wang Zhiming, Women Entering the Elite Group: A Limited Progress, 4 FronTIERS EDUC. ChINA 27, 47 (2009).

25. Yang Jingrui \& $\mathrm{Na}$ Jia, Women Are 10\% More Than Men in the Judicial Examination, LEGAL EVENING NEWS, July 1, 2010, available at http://earning.sohu.com/ 20100906/n274732985.shtml.

26. $I d$.

27. Li Tiezhu (李铁柱), fa xue zhuan jia:guo nei fa xue yuan nan nü bi li shi heng (法学专家: 国内法学院男女比例失衡) [Legal Expert: The Law Students' Ratio is Imbalanced in China], JIAN CHA RI BAO (检察日报) [PROCuRATORIAL DAILY], June 20, 2011, at http://news.jcrb.com/jxsw/201106/t20110620_558993.html.

28. Jingrui \& Jia, supra note 25.

29. Liu Bohong \& Li Yani, Gender Issues in Chinese Educations. 1 J. OF YUNNAN NATIONALITIES UNIVERSITY 57 (2011). 
students in physics; 78.3 percent were men students in mechanics and engineering; 73.1 percent were men students in mathematics; 65.4 percent were men students in computer technology; and 65.3 percent were men students in chemistry and chemical engineering. ${ }^{30}$ In addition, Chinese universities select students based on a nationwide entrance examination, and women generally perform better on this exam than men. ${ }^{31}$ However, female students have more difficulties than men in finding jobs after graduation, leaving some female graduates with no alternative but to continue studying for a master's or even a $\mathrm{Ph} . \mathrm{D}$. I believe that is one of the reasons why the percentage of female students is greater than males among applicants for higher degrees in law.

\section{B. Female Law Faculty in Legal Education}

As the number of female university students rises, so does the number of female faculty members at China's colleges and universities. In 1951, women accounted for only 10.98 percent of the total faculty members in higher education, ${ }^{32}$ but the figure had jumped to 45.62 percent by $2008 .^{33}$

30. Ma Wanhua, The History, Current Situation, and Problems in the Development of Higher Education of Chinese Women, 3 EDUC. DEV. STUD. 4 (2005).

31. Jingrui \& Jia, supra note 25.

32. ZHONGGUO JIAOYU NIANJIAN 1949-1981 (中国教育年监 1949-1981), supra note 17, at 974.

33. ZHONGGUO JLAOYU TONG J NIANJIAN 2009 (中国教育年鉴 2009), supra note 18, at 108. 
Table 5. Full-Time Female Faculty in Higher Education Intuitions

\begin{tabular}{|c|c|c|c|c|c|c|c|}
\hline Year & $1951^{\mathrm{a}}$ & $1961^{\mathrm{b}}$ & $1973^{\mathrm{c}}$ & $1981^{\mathrm{d}}$ & $1991^{\mathrm{e}}$ & $2001^{\mathrm{f}}$ & $2008 \mathrm{~g}$ \\
\hline $\begin{array}{c}\text { Number of } \\
\text { female } \\
\text { faculty } \\
\text { members }\end{array}$ & 1,902 & 33,608 & 30,000 & 64,455 & 115,800 & 210,500 & 564,600 \\
\hline $\begin{array}{c}\text { Percentage } \\
\text { of all faculty } \\
\text { members }\end{array}$ & $10.98 \%$ & $21.17 \%$ & $22.73 \%$ & $25.79 \%$ & $29.6 \%$ & $39.57 \%$ & $45.62 \%$ \\
\hline
\end{tabular}

a Zhongguo Jiaoyu Nianjian 1949-1981 (中国教育年鉴 1949-1981) [China Education Yearbook 1949-1981] 974 (1981).

b Zhongguo Jiaoyu Nianjian 1949-1981 (中国教育年鉴 1949-1981) [China Education Yearbook 1949-1981] 974 (1981).

c Zhongguo Jiaoyu Nianjian 1949-1981 (中国教育年鉴 1949-1981) [Chinà Education Yearbook 1949-1981] 974 (1981) (No data available for 1966-1972).

d Zhongguo Jiaoyu Nianjian 1949-1981 (中国教育年鉴 1949-1981) [China Education Yearbook 1949-1981] 974 (1981).

e Zhongguo Jiaoyu Nianjian 1992 (中国教育年篮 1992) [China Education Yearbook 1992] 56 (1992).

f Zhongguo Jiaoyu Nianjian 2002 (中国教育年鉴 2002) [China Education Yearbook 2002] 92 (2002).

g Zhongguo Jiaoyu Nianjian 2009 (中国教育年鉴 2009) [China Education Yearbook 2009] $108(2009)$.

As there are no official statistics about legal education in terms of students or faculty in China, I collected data from law schools' websites, looking specifically at faculty name lists. However, of the 607 law schools in China at the end of 2007 , only a relatively small number included biographies for their faculties; many only provided a list of names without gender information. In 2008 and 2012, my research assistant and I checked twenty-six law schools websites, which provided faculty members' names, and tried to figure out the gender of each for the purpose of calculating a gender percentage.

In early 2008, the twenty-six law schools checked had a total of 1,832 law faculty members. Of these, the gender of 1,821 could be determined, and of those, 566, or 31.08 percent, were female. The highest percentage of female law faculty members at any single school was 52.17 percent, and the lowest percentage was 14.91 percent. ${ }^{34}$

34. The data was collected from the websites of these law schools. 
In July 2012 , the total number of law faculty members at the same twenty-six law schools was 1,700 , with 1,689 of known gender; the total number of female faculty members was 504-29.84 percent of the total-and the total number of male faculty members was $1,185-70.16$ percent of the total. The percentage of women among the faculty at the Law School of Minzu University is the highest of the twenty-six schools, accounting for 51.11 percent of the total number of faculty members. The percentage of women among the faculty at Tsinghua University Law School is the lowest at 14.55 percent. ${ }^{35}$ This data illustrates that there has been no substantial change during this period in the percentage of female faculty members at law schools within China.

Table 6. The Gender Ratio in Twenty-Six Law Schools in 2012

\begin{tabular}{|l|l|l|l|}
\hline \multirow{2}{*}{ Law School } & \multicolumn{3}{|c|}{ Law faculty } \\
\cline { 2 - 4 } & $\begin{array}{l}\text { Total } \\
\text { number }\end{array}$ & $\begin{array}{l}\text { Men } \\
\text { (Percentage) }\end{array}$ & $\begin{array}{l}\text { Women } \\
\text { (Percentage) }\end{array}$ \\
\hline Peking University & 87 & $\begin{array}{l}67 \\
(77.01 \%)\end{array}$ & $\begin{array}{l}20 \\
(22.99 \%)\end{array}$ \\
\hline Tsinghua University & 55 & $\begin{array}{l}47 \\
(85.45 \%)\end{array}$ & $\begin{array}{l}8 \\
(14.55 \%)\end{array}$ \\
\hline Renmin University & 130 & $\begin{array}{l}102 \\
(78.46 \%)\end{array}$ & $\begin{array}{l}28 \\
(21.54 \%)\end{array}$ \\
\hline Minzu University & 45 & $\begin{array}{l}22 \\
(48.89 \%)\end{array}$ & $\begin{array}{l}23 \\
(51.11 \%)\end{array}$ \\
\hline Wuhan University & & $\begin{array}{l}81 \\
(81 \%)\end{array}$ & $\begin{array}{l}19 \\
(19 \%)\end{array}$ \\
\hline Zhongshan University & 100 & $\begin{array}{l}36 \\
(73.47 \%)\end{array}$ & $\begin{array}{l}13 \\
(26.53 \%)\end{array}$ \\
\hline Chinese Academy of Social & 102 & $\begin{array}{l}77 \\
(75.49 \%)\end{array}$ & $\begin{array}{l}25 \\
(24.51 \%)\end{array}$ \\
Sciences & 49 & $\begin{array}{l}59 \\
(70.24 \%)\end{array}$ & $\begin{array}{l}25 \\
(29.76 \%)\end{array}$ \\
\hline China University of Political & 84 & 58 & 38 \\
Science and Law & & $(60.42 \%)$ & $(39.58 \%)$ \\
\hline Jilin University & 96 & $\begin{array}{l}52 \\
(73.24 \%)\end{array}$ & $\begin{array}{l}19 \\
(26.76 \%)\end{array}$ \\
\hline $\begin{array}{l}\text { Southwest University of } \\
\text { Political Science and Law } \\
\text { (Administrative Law School) }\end{array}$ & 71 & & \\
\hline Southwest University of & 63 & 44 & 19 \\
\hline
\end{tabular}

35. The data was collected from the websites of these law schools. 


\begin{tabular}{|c|c|c|c|}
\hline $\begin{array}{l}\text { Political Science and Law } \\
\text { (Civil Law School) }\end{array}$ & & $(69.84 \%)$ & $(30.16 \%)$ \\
\hline $\begin{array}{l}\text { Southwest University of } \\
\text { Political Science and Law } \\
\text { (Economic Law School) }\end{array}$ & 49 & $\begin{array}{l}30 \\
(61.22 \%)\end{array}$ & $\begin{array}{l}19 \\
(38.78 \%)\end{array}$ \\
\hline $\begin{array}{l}\text { Central University of } \\
\text { Finance and Economics }\end{array}$ & 45 & $\begin{array}{l}33 \\
(73.33 \%)\end{array}$ & $\begin{array}{l}12 \\
(26.67 \%)\end{array}$ \\
\hline Nankai University & 57 & $\begin{array}{l}42 \\
(73.68 \%)\end{array}$ & $\begin{array}{l}15 \\
(26.32 \%)\end{array}$ \\
\hline Tongji University & 44 & $\begin{array}{l}29 \\
(65.91 \%)\end{array}$ & $\begin{array}{l}15 \\
(34.09 \%)\end{array}$ \\
\hline Shanghai University & 46 & $\begin{array}{l}28 \\
(60.87 \%)\end{array}$ & $\begin{array}{l}18 \\
(39.13 \%)\end{array}$ \\
\hline Fudan University & 55 & $\begin{array}{l}44 \\
(80 \%)\end{array}$ & $\begin{array}{l}11 \\
(20 \%)\end{array}$ \\
\hline $\begin{array}{l}\text { Shanghai Jiaotong } \\
\text { University }\end{array}$ & 54 & $\begin{array}{l}44 \\
(81.48 \%)\end{array}$ & $\begin{array}{l}10 \\
(18.52 \%)\end{array}$ \\
\hline Nanjing Normal University & 54 & $\begin{array}{l}43 \\
(79.63 \%)\end{array}$ & $\begin{array}{l}11 \\
(20.37 \%)\end{array}$ \\
\hline Nanjing University & 69 & $\begin{array}{l}46 \\
(66.67 \%) \\
\end{array}$ & $\begin{array}{l}23 \\
(33.33 \%) \\
\end{array}$ \\
\hline Xiamen University & 79 & $\begin{array}{l}55 \\
(69.62 \%)\end{array}$ & $\begin{array}{l}24 \\
(30.38 \%)\end{array}$ \\
\hline Guizhou University & 91 & $\begin{array}{l}49 \\
(53.85 \%) \\
\end{array}$ & $\begin{array}{l}42 \\
(46.15 \%) \\
\end{array}$ \\
\hline Yunnan University & 42 & $\begin{array}{l}28 \\
(66.67 \%)\end{array}$ & $\begin{array}{l}14 \\
(33.33 \%)\end{array}$ \\
\hline $\begin{array}{l}\text { Daliann Maritime } \\
\text { University }\end{array}$ & 50 & $\begin{array}{l}26 \\
(52 \%) \\
\end{array}$ & $\begin{array}{l}24 \\
(48 \%) \\
\end{array}$ \\
\hline Central South University & 38 & $\begin{array}{l}25 \\
(65.79 \%)\end{array}$ & $\begin{array}{l}13 \\
(34.21 \%)\end{array}$ \\
\hline Ji'nan University & 45 & $\begin{array}{l}18 \\
(52.94 \%)\end{array}$ & $\begin{array}{l}16 \\
(47.06 \%)\end{array}$ \\
\hline
\end{tabular}

Note: The data was collected from the websites of these law schools in July 2012. For Ji'nan University, there were only 34 out of 45 faculty members whose gender could be determined

In China, little research has been done on women's entry into legal education and the legal profession, or their subsequent development within their careers, and it is very difficult to collect relevant information and data. By contrast, data about women in law schools and the legal profession in the United States can be found by visiting the 
websites of the American Bar Association and the Association of American Law Schools. ${ }^{36}$ As previously mentioned, gender statistics for legal education in China are almost nonexistent. The lack of such statistics is simply a reflection of the lack of attention paid to gender in the studies about China's legal sector. Although the numbers and percentages of women in legal education and legal occupations would not explain all the issues, such information is a starting point for studying and understanding women in the aforementioned areas.

\section{GENDER DisCRIMINATION AND BIAS IN LEGAL EDUCATION}

Although women have made significant gains in legal education, they are still facing gender discrimination and bias in the legal sector.

\section{A. Equality of Educational Opportunity Has Not Been Achieved}

Due to the lack of official gender statistics for legal education, we are not able to prove that there are more female law students than male law students nationwide. In any case, the fact that there may be more female than male law students in Chinese law schools does not mean that equality has been achieved with respect to school admissions. ${ }^{37}$ According to the interview that I conducted in 2008, even with a higher percentage of female masters and Ph.D students than male students, the existing gender bias in the enrollment process itself reflects that gender discrimination and bias exist in legal education. ${ }^{38}$

In 2008, I conducted surveys through questionnaires concerning gender discrimination and prejudice in legal education and the legal profession, which I distributed to law faculty and law students from five law schools in China. 39 With respect to the question "Do professors have a gender preference when enrolling postgraduates majoring in law?" 45.8 percent of graduate students believed that professors give priority

36. See Statistics, AMERICAN BAR AsSOCIATION, http://www.americanbar.org/groups/le gal_education/resources/statistics.html (last visited Sept. 1. 2013); AALS Statistical Report on Law Faculty, AssOC. OF AMERICAN LAW SCHOOLS, http://www.aals.org/resources _statistical.php (last visited Sept. 1, 2013).

37. Lian Na, Female Graduate Student Experiences Discrimination, VBoth Mentor and Employer More Prefer Men, CHINA YouTH DAILY, (Feb. 26, 2007), available at http://learning.sohu.com/20070226/n248348249.shtml.

38. The enrollment process for the postgraduate student usually includes a paper exam and oral test. The oral test is more flexible, which make it possible for the professors to give higher scores to male students.

39. The schools that received surveys were Renmin University Law School, Hainan University Law School, Anhui Normal University Law School, China University of Political Science and Law, and Wuhan University Law School. 
to male students during the enrollment process. ${ }^{40}$ The questionnaire given to law faculty included a similar question: "All other conditions being the same for two candidates, who do you prefer, a male applicant or a female applicant?" In response, 29.9 percent of law faculty indicated that they would prefer the male applicant. Only 4.8 percent of the law faculty respondents said they would prefer the female applicant; the other 67.3 percent indicated that they had no gender preference.

Ten of the eleven graduate students I interviewed in early 2008 indicated their view that professors prefer male students when asked about gender bias in enrollment. This was particularly the case, in their minds, when the supervising professor is also male. Indeed, some professors have publicly expressed their gender preference, with the result that preference for male students has essentially become an unwritten rule. Interview responses include the following:

It is absolute [that gender preference exists], and I have discussed it with many people. ... From an academic perspective, it is not absolutely impossible for females to get engaged in academic fields, but for the most part, the connection between female students and academic life is not close and the gap cannot be narrowed. . . Female students are not suitable to be scholars. Although nowadays there are some female scholars and professors, this will not last in the long run because the thoughts [of females] are not profound, which is a crucial reason. . . . Both male and female professors tend to enroll male students, but especially male professors . . . [because] it is easier to control male postgraduates.

\section{-A first-year male postgraduate majoring in jurisprudence}

Professors are more willing to enroll male students, and some even don't enroll female students at all. Perhaps professors consider male students to have more academic ability. ... The academic mentor I applied for didn't enroll female students. . . It is unfair, but it is a

40. $13.54 \%$ of the graduate students believed that most law faculty give priority to male students during the enrollment process; $21.9 \%$ of the graduate students believed that some law faculty give priority to male students during the enrollment process; $10.4 \%$ of the graduate students believed that a few law faculty give priority to male students during the enrollment process. 
reality, and I don't have much else to say. I am not a feminist. . . The only thing a woman can do is try to be stronger.

-A first-year female postgraduate majoring in jurisprudence

In criminal law, [advisors' preference for men] is not very strong, but in civil and commercial law, [the advisors' preference for men] is strong. Some academic advisors directly indicated that they didn't enroll female students. Male students can help with [the professor's] work and are not afraid of working overtime. Besides, other people will gossip about [a male professor] having a female student. Some believe that male students have greater academic ability, but I don't think so.

-A first-year female postgraduate majoring in criminal law

Some professors prefer male students in order to avoid arousing suspicion, because advisors are mostly male, and conversations between men are much easier. They have similar knowledge systems and modes of thinking; male students are much stronger, more competent, and make less trouble (which is especially evident among science students, but also evident among liberal arts students), while female students seem delicate and advisors would feel embarrassed to assign them work. Sometimes preference is given to the male students just because advisors prefer students who are like themselves. Take our faculty as an example, some advisors enrolled only male students for no reason, no matter how outstanding the female students are or how frequently they communicate.

-A first-year female postgraduate majoring in jurisprudence

As far as I know, a male academic advisor in The International Economic Law School is a henpecked husband, so he enrolls no female students, or only ugly ones. The advisors in criminal law don't tend to enroll 
female students either because some projects require business trips and it is not suitable for female students [to travel alone]. Another reason is the preference of supervisors themselves.

-A first-year female postgraduate majoring in jurisprudence

Some Ph.D academic advisors tend to enroll male students. For example, advisor [X] rarely enrolls female students, but advisor [X] enrolled female students this year for the first time. Some advisors think that women are not suitable for jurisprudence; and some are forbidden by their wives from enrolling female students. ... My advisor announced at the beginning of semester that he would not have any meals alone with female students.

-A female Ph.D student

Academic advisors of graduate and Ph.D students prefer male students, and some even expressed it explicitly, which makes it an unwritten rule. The main reason for the phenomenon is that the male students' mode of thinking is more suitable for legal research. In addition, some academic advisors are concerned that female students could not completely concentrate on their studies, and that getting married or giving birth to babies would probably affect their studies.

\section{-A female Ph.D student}

In the individual interviews, two female students indicated that although it was not proper for supervisors to prefer male students, even though it was still understandable, and they felt frustrated about the phenomenon.

\section{B. Women Are Still at the Bottom of the Pyramid in Legal Education}

In China, university faculty fall into one of these four positions: professor, associate professor, instructor, and assistant instructor. 
Table 7. Professional Titles of Full-time Female Faculty in
Higher Education Institutions

\begin{tabular}{llll}
\hline Year 2010 & Total & $\begin{array}{l}\text { Number of } \\
\text { Women }\end{array}$ & $\begin{array}{l}\text { Percentage of } \\
\text { Total }\end{array}$ \\
\hline Professors & 152,115 & 40,842 & $26.85 \%$ \\
Associate Professors & 394,299 & 169,272 & $42.93 \%$ \\
Instructors & 542,174 & 272,499 & $50.26 \%$ \\
Assistant Instructors & 244,238 & 134,228 & $54.96 \%$ \\
\hline
\end{tabular}

Source: Zhongguo Jiaoyu tongji Nianjian 2010 (中国教育统计年鉴 2010) [China Education Statistics Yearbook 2010] 44-45 (2010).

The table above indicates that the occupational status of women showed an obvious vertical gender division even in the educational profession, which is generally considered to be most suitable for women. ${ }^{41}$. The percentage of female full-time faculty members with assistant instructor rank is greater, and the percentage of instructor is almost equal to the percentage of male full-time faculty members. However, as one rises through the ranks to associate professor and professor status, the percentage of women decreases. The statistics tell us that the percentage of female full-time faculty in senior professorial positions is small, resulting in their vulnerable status in the academic power structure.

As mentioned, I selected twenty-six law schools that had comparatively sufficient website information and conducted a statistical study on faculty gender and rank. While we believe that the data obtained from these websites was not completely accurate due to delays in website updates and statistical discrepancy, we can get a rough idea of law faculty members' ranks and the gender percentage through the following statistics collected from the twenty-six schools in July 2012:

The gender of a total of 697 professors in the twenty-six law schools is known. There are 153 female professors (22 percent), while the remaining 544 (78 percent) are male. In addition, there are 647 associate professors of known gender. A total of 219 (33.85 percent) are female and 428 (66.15 percent) are male. Finally, the gender is known for 345 instructors, with 132 (38.26 percent) female instructors and 213 (61.74 percent) male instructors.

The percentage of female professors at the Law School of Dalian Maritime University is the highest, accounting for 50 percent; the percentage of female professors in Administrative Law School of the

41. Liu Bohong \& Li Yani, supra note 29 , at 58. 
Southwest University of Political Science and Law is lowest with only 5.56 percent of the faculty members. The highest percentage of female associate professors is at the Law School of Minzu University, with 70 percent of associate professors being women. Meanwhile, the percentage of female associate professors at the Law School of the Chinese Academy of Social Sciences is the lowest, at only 17.86 percent. The Civil Law School of Southwest University of Political Science and Law has the highest percentage of female instructors, with females accounting for 64.29 percent. The percentage of female instructors in Law School of Nanjing Normal University is the lowest, with 12.5 percent female instructors.

Table 8. Professional Titles, Number and Percentage of Female Faculty in the Twenty-Six Law Schools in 2012

\begin{tabular}{|c|c|c|c|c|c|c|}
\hline \multirow[t]{2}{*}{ Law School } & \multicolumn{2}{|c|}{ Instructor } & \multicolumn{2}{|c|}{$\begin{array}{l}\text { Associate } \\
\text { Professor }\end{array}$} & \multicolumn{2}{|c|}{ Professor } \\
\hline & Total & $\begin{array}{c}\text { Female } \\
\text { (Percentage) }\end{array}$ & Total & $\begin{array}{l}\text { Female } \\
\text { (Percentage) }\end{array}$ & Total & $\begin{array}{l}\text { Female } \\
\text { (Percentage) }\end{array}$ \\
\hline $\begin{array}{l}\text { Peking } \\
\text { University }\end{array}$ & 8 & $\begin{array}{l}4 \\
(50 \%)\end{array}$ & 30 & $\begin{array}{l}10 \\
(33.33 \%)\end{array}$ & 49 & $\begin{array}{l}6 \\
(12.24 \%) \\
\end{array}$ \\
\hline $\begin{array}{l}\text { Tsinghua } \\
\text { University }\end{array}$ & 4 & $\begin{array}{l}1 \\
(25 \%)\end{array}$ & 20 & $\begin{array}{l}5 \\
(25 \%) \\
\end{array}$ & 31 & $\begin{array}{l}2 \\
(6.45 \%) \\
\end{array}$ \\
\hline $\begin{array}{l}\text { Renmin } \\
\text { University }\end{array}$ & 13 & $\begin{array}{l}5 \\
(38.46 \%)\end{array}$ & 41 & $\begin{array}{l}9 \\
(21.95 \%) \\
\end{array}$ & 76 & $\begin{array}{l}14 \\
(18.42 \%)\end{array}$ \\
\hline $\begin{array}{l}\text { Minzu } \\
\text { University }\end{array}$ & 9 & $\begin{array}{l}2 \\
(22.22 \%)\end{array}$ & 20 & $\begin{array}{l}14 \\
(70 \%)\end{array}$ & 16 & $\begin{array}{l}7 \\
(43.75 \%)\end{array}$ \\
\hline $\begin{array}{l}\text { Wuhan } \\
\text { University }\end{array}$ & 10 & $\begin{array}{l}2 \\
(20 \%) \\
\end{array}$ & 36 & $\begin{array}{l}7 \\
(19.44 \%) \\
\end{array}$ & 54 & $\begin{array}{l}10 \\
(18.52 \%)\end{array}$ \\
\hline $\begin{array}{l}\text { Zhongshan } \\
\text { University }\end{array}$ & 5 & $\begin{array}{l}2 \\
(40 \%)\end{array}$ & 24 & $\begin{array}{l}7 \\
(29.17 \%) \\
\end{array}$ & 20 & $\begin{array}{l}4 \\
(20 \%) \\
\end{array}$ \\
\hline $\begin{array}{l}\text { Chinese } \\
\text { Academy of } \\
\text { Social Sciences }\end{array}$ & 15 & $\begin{array}{l}6 \\
(40 \%)\end{array}$ & 28 & $\begin{array}{l}5 \\
(17.86 \%)\end{array}$ & 59 & $\begin{array}{l}14 \\
(23.73 \%)\end{array}$ \\
\hline $\begin{array}{l}\text { China } \\
\text { University of } \\
\text { Political } \\
\text { Science and } \\
\text { Law }\end{array}$ & 13 & $\begin{array}{l}4 \\
(30.77 \%)\end{array}$ & 38 & $\begin{array}{l}12 \\
(31.58 \%)\end{array}$ & 33 & $\begin{array}{l}9 \\
(27.27 \%)\end{array}$ \\
\hline Jilin University & 31 & $\begin{array}{l}14 \\
(45.16 \%)\end{array}$ & 28 & $\begin{array}{l}8 \\
(28.57 \%)\end{array}$ & 37 & $\begin{array}{l}16 \\
(43.24 \%)\end{array}$ \\
\hline $\begin{array}{l}\text { Southwest } \\
\text { University of } \\
\text { Political } \\
\text { Science and } \\
\text { Law } \\
\text { (Administrative } \\
\text { Law School) } \\
\end{array}$ & 19 & $\begin{array}{l}5 \\
(26.32 \%)\end{array}$ & 34 & $\begin{array}{l}13 \\
(38.24 \%)\end{array}$ & 18 & $\begin{array}{l}1 \\
5.56 \%\end{array}$ \\
\hline
\end{tabular}




\begin{tabular}{|c|c|c|c|c|c|c|}
\hline $\begin{array}{l}\text { Southwest } \\
\text { University of } \\
\text { Political } \\
\text { Science and } \\
\text { Law (Civil Law } \\
\text { School) }\end{array}$ & 14 & $\begin{array}{l}9 \\
(64.29 \%)\end{array}$ & 29 & $\begin{array}{l}6 \\
(20.69 \%)\end{array}$ & 20 & $\begin{array}{l}4 \\
(20 \%)\end{array}$ \\
\hline $\begin{array}{l}\text { Southwest } \\
\text { University of } \\
\text { Political } \\
\text { Science and } \\
\text { Law (Economic } \\
\text { Law School) }\end{array}$ & 9 & $\begin{array}{l}4 \\
(44.44 \%)\end{array}$ & 28 & $\begin{array}{l}11 \\
(39.29 \%)\end{array}$ & 12 & $\begin{array}{l}4 \\
(33.33 \%)\end{array}$ \\
\hline $\begin{array}{l}\text { Central } \\
\text { University of } \\
\text { Finance and } \\
\text { Economics }\end{array}$ & 14 & $\begin{array}{l}4 \\
(28.57 \%)\end{array}$ & 19 & $\begin{array}{l}7 \\
(36.84 \%)\end{array}$ & 12 & $\begin{array}{l}1 \\
(8.33 \%)\end{array}$ \\
\hline $\begin{array}{l}\text { Nankai } \\
\text { University }\end{array}$ & 15 & $\begin{array}{l}5 \\
(33.33 \%)\end{array}$ & 20 & $\begin{array}{l}7 \\
(35 \%) \\
\end{array}$ & 22 & $\begin{array}{l}3 \\
(13.64 \%)\end{array}$ \\
\hline $\begin{array}{l}\text { Tongji } \\
\text { University }\end{array}$ & 19 & $\begin{array}{l}7 \\
(36.84 \%)\end{array}$ & 15 & $\begin{array}{l}5 \\
(33.33 \%)\end{array}$ & 10 & $\begin{array}{l}3 \\
(30 \%)\end{array}$ \\
\hline $\begin{array}{l}\text { Shanghai } \\
\text { University }\end{array}$ & 15 & $\begin{array}{l}5 \\
(33.33 \%) \\
\end{array}$ & 19 & $\begin{array}{l}8 \\
(42.11 \%)\end{array}$ & 12 & $\begin{array}{l}5 \\
(41.67 \%) \\
\end{array}$ \\
\hline $\begin{array}{l}\text { Fudan } \\
\text { University }\end{array}$ & 6 & $\begin{array}{l}2 \\
(33.33 \%)\end{array}$ & 18 & $\begin{array}{l}6 \\
(33.33 \%)\end{array}$ & 31 & $\begin{array}{l}3 \\
(9.68 \%)\end{array}$ \\
\hline $\begin{array}{l}\text { Shanghai } \\
\text { Jiaotong } \\
\text { University }\end{array}$ & 11 & $\begin{array}{l}2 \\
(18.18 \%)\end{array}$ & 19 & $\begin{array}{l}6 \\
(31.58 \%)\end{array}$ & 24 & $\begin{array}{l}2 \\
(8.33 \%)\end{array}$ \\
\hline $\begin{array}{l}\text { Nanjing } \\
\text { Normal } \\
\text { University }\end{array}$ & 8 & $\begin{array}{l}1 \\
(12.5 \%)\end{array}$ & 21 & $\begin{array}{l}8 \\
(38.10 \%)\end{array}$ & 25 & $\begin{array}{l}2 \\
(8 \%)\end{array}$ \\
\hline $\begin{array}{l}\text { Nanjing } \\
\text { University }\end{array}$ & 15 & $\begin{array}{l}5 \\
(33.33 \%)\end{array}$ & 29 & $\begin{array}{l}12 \\
(41.38 \%)\end{array}$ & 25 & $\begin{array}{l}6 \\
(24 \%) \\
\end{array}$ \\
\hline $\begin{array}{l}\text { Xiamen } \\
\text { University }\end{array}$ & 24 & $\begin{array}{l}8 \\
(33.33 \%) \\
\end{array}$ & 22 & $\begin{array}{l}4 \\
(18.18 \%) \\
\end{array}$ & 33 & $\begin{array}{l}12 \\
(36.36 \%)\end{array}$ \\
\hline $\begin{array}{l}\text { Guizhou } \\
\text { University }\end{array}$ & 34 & $\begin{array}{l}19 \\
(55.88 \%)\end{array}$ & 39 & $\begin{array}{l}16 \\
(41.03 \%)\end{array}$ & 18 & $\begin{array}{l}7 \\
(38.89 \%)\end{array}$ \\
\hline $\begin{array}{l}\text { Yunnan } \\
\text { University }\end{array}$ & 0 & 0 & 21 & $\begin{array}{l}11 \\
(52.38 \%)\end{array}$ & 21 & $\begin{array}{l}3 \\
(14.29 \%)\end{array}$ \\
\hline $\begin{array}{l}\text { Daliann } \\
\text { Maritime } \\
\text { University }\end{array}$ & 14 & $\begin{array}{l}7 \\
(50 \%)\end{array}$ & 18 & $\begin{array}{l}8 \\
(44.44 \%)\end{array}$ & 18 & $\begin{array}{l}9 \\
(50 \%)\end{array}$ \\
\hline $\begin{array}{l}\text { Central South } \\
\text { University }\end{array}$ & 20 & $\begin{array}{l}9 \\
(45 \%) \\
\end{array}$ & 9 & $\begin{array}{l}3 \\
(33.33 \%)\end{array}$ & 9 & $\begin{array}{l}1 \\
(11.11 \%)\end{array}$ \\
\hline $\begin{array}{l}\text { Ji'nan } \\
\text { University }\end{array}$ & 11 & 0 & 22 & $\begin{array}{l}11 \\
(50 \%)\end{array}$ & 12 & $\begin{array}{l}5 \\
(41.67 \%)\end{array}$ \\
\hline
\end{tabular}

Note: The data was collected from the websites of these law schools in July 2012. 
Table 9. Summary of Professional Titles, Numbers, and Percentages of Female Faculty at the Twenty-Six Law Schools

\begin{tabular}{lcc}
$\begin{array}{l}\text { Female Faculty Members in } \\
\text { Law Schools }\end{array}$ & $\begin{array}{c}\text { Total } \\
\text { Number }\end{array}$ & Percentage \\
\hline $\begin{array}{l}\text { Female Faculty Members } \\
\text { Overall }\end{array}$ & 504 & $29.65 \%$ \\
Professors & 153 & $21.95 \%$ \\
Associate Professors & 219 & $33.85 \%$ \\
Instructors & 132 & $38.26 \%$ \\
\hline
\end{tabular}

In the twenty-six law schools I surveyed, the proportion of female faculty is very low, less than 30 percent, so even the proportion of women instructors is also less than half. However, as we can see from the above statistics, the distribution trend of rank, number, and percentage of female faculty in legal education is consistent with that of higher education as a whole, which concentrates most female faculty members in the lower ranking positions. Female faculty is still at the bottom of the pyramid in the law schools. The closer one gets to the top of the pyramid, the smaller the percentage of women becomes. The fact that female faculty members account for a small portion of the senior ranks reflects their weak position in legal research and education.

There are many obstacles to a female faculty member being promoted, but the sex discrimination and prejudice is one of them. ${ }^{42}$ For example, retirement at different ages between males and females goes against females' career development. In China, women have to retire five to ten years earlier than men. The National Ministry of Human Resources issued the Notice regarding the Senior Experts' Retirement Issues (No. 5 1990), which clearly provided that "female senior expert[s] may retire at the age of sixty if they want and they are in good health conditions to continue to work." 43 However, in some cities, organizations disregard the unwillingness of the female senior professional and technical experts, requiring them to retire at the age of fifty-five. The third wave of Chinese women social status survey shows that the

42. Zhang Jianqi (张建奇), Studies on the Status and Current Situation of Female Faculty in Chinese Higher Education [我国高校女教师地位现状之研究], 4 RESEARCH ON EDUCATION TSINGHUA UNIVERSITY, 56-61 (1997).

43. Notice, Senior Experts' Retirement Issues, No. 5, NATIONAL MINISTRY OF HuMAN RESOURCES (1990). 
average retirement age for female senior professional and technical expert is 52.5.44 This early retirement causes gender inequality in law schools, in terms of teaching and science researchers, because to a certain extent it causes greater hindrances and difficulties for female faculty in terms of receiving research funding and promotion to higher academic positions. 45

Moreover, females are facing greater family responsibilities, but smaller pressure for career successes, than males. ${ }^{46}$ Nature has given females the organic ability to give birth to and feed children; the traditional social division has developed and extended this organic ability to the extent that caring for all of the inferior family affairs is the born responsibility of women. In an interview I conducted, a male law faculty member mentioned, "The social division in gender has been developed naturally, which is rational. Women give birth to children; therefore women should undoubtedly take charge of their fosterage. The organic function has decided the differences of social division of men and women." Modern ideas on the equality of men and women has allowed women to manage walking into public social fields from private family fields. However, the inertia of traditional social division in gender is still functioning. According to major indication statistics on the investigation of women's social status in 2000 , on average, all around the nation, the time which women have spent on family labor is 2.73 times more than that of men; in cities, the time which urban women have spent on family labor is 2.48 times more than that of men. ${ }^{47}$

Besides, gender in social culture doesn't ask women the same requirements as men. In the interview, a male law faculty has considered, "women should take the family life as the most important thing and men should take career as the most important thing." The gendered social division called "Women [to] manage the interior and men [to] manage the exterior" in Chinese traditional culture, with the moral criteria of the "virtuous wife and good mother," "serving husband and educating children," and the criteria of social values recognition and valuation. These have immersed women in collisions between the pursuit of career role and the definition of traditional social status, which is hard to reconcile.

44. Yang Yujing (杨玉静), Adhere to the Equality between Men and Women and fully Implementing Female Senior Experts Retirement Policy [坚持男女平等, 全面落实女性高级专家退休政策], available at http://www.wsic.ac.cn/hotcom mentary/82689.htm.

45. Zhang Jianqi, supra note 42 , at 58 .

46. Id. at 59 .

47. Zhang Aishu, Self-Recognition and Social Recognition of Female Managers at Universities and Colleges, 4 ACAD. J. OF CHINA UNIV. OF MINING IND. 100-04 (2006). 


\section{Women Facing Glass Ceiling in Law Schools}

Women are in a weak position not only with respect to academic power in legal education, but also with respect to the allocation of administrative power. According to the latest statistics from the Association of American Law Schools in 2009, 20.6 percent of U.S. law school deans, 45.7 percent of deputy deans, and 66.2 percent of assistant deans are women. ${ }^{48} \mathrm{It}$ is thus clear that when it comes to administrative positions in legal education, women are again distributed like a pyramid.

We still lack official statistical data regarding the gender breakdown of administrative positions in Chinese law schools, so I researched women's administrative positions in legal education by conducting statistical analysis on the percentage of female deans and the gender structure of the dean-level administrators in law schools.

In late 2012, I conducted a statistical analysis of the universities and colleges participating in "Project 211" with respect to the gender of their law school deans. Project 211 is the Chinese government's new endeavor aimed at strengthening about 100 institutions of higher education and key disciplinary areas as a national priority for the 21 st century. There are 112 universities total, which have 118 law schools that belonged to "Project 211" in 2012. Among them, there are eightyfour law schools that provide relevant information. Of the eighty-four law schools included, only six had female law school deans, meaning the male to female gender ratio was $13: 1$, with women accounting for 7.1 percent and men accounting for 92.9 percent of law school deans. ${ }^{49}$ Although I was not able to get nationwide data, we can still see from the above statistics that the percentage of female deans in Chinese law schools is probably far lower than the United States' rate of 20.6 percent.

We also calculated dean-level administrators at the eighty-four law schools that disclosed complete information on their websites. In China, there are more than six hundred different sizes of law schools, which have different organizational structure and leading divisions. Generally speaking, dean-level administrators include the dean, deputy deans, chief party secretary, and deputy party secretary. The people in these

48. Comm'n on Women In the Profession, Am. Bar Ass'n, A Current Glance at WOMEN IN THE LAW 2009, 3 (2009), available at https://dl-web.dropbox.com/get/Liu/Sourc es/FN32_CurrentGlanceStatistics2009.authcheckdam.pdf?w=AAC9qH01gG5asywMCcfHA TPUmXPxkxBJBT1IWZ9yR4sufA.

49. The data sources for three law schools came from information on the law schools' websites in March 2013. For the other eighty-one law schools, data came from information on the law schools' websites in November of 2012. 
party secretary positions serve as liaisons between the school and the Chinese Communist Party. A Dean is responsible for overall teaching, academic research, and administrative matters for the school. The Deputy Deans report to the Dean in various areas, such as academic, research, administration, and human resources.

We found that, except for the Minzu University, which has more female dean-level administrators than male counterparts, at all the other eighty-three law schools there are more male dean-level administrators than females. Moreover, there are eighteen law schools that do not have any female dean-level administrators. Among the sixty-six law schools with female dean-level administrators, thirty-nine have only one female. In the only university mentioned above which has more female dean-level administrators than male ones, the dean is male. Among the eighty-four law schools researched, only six have female deans.

Table 12. Gender Structure of Leaders in Some Law Schools in China

\begin{tabular}{lc}
\hline Chief Secretary of the CCP50 & 13 \\
Deputy Secretary of the CCP & 28 \\
Dean & 6 \\
Deputy Dean & 37 \\
Joint Chief Secretary of the CCP & 3 \\
$\quad$ \& Deputy Dean & 2 \\
Joint Deputy Secretary of the CCP & \\
$\quad$ \& Deputy Dean & 18 \\
No Women in Leadership Positions & \\
\hline
\end{tabular}

Note: The data is from the universities' website in the end of 2012.

The universities are ranked by geographic area, irrespective of college and university rankings. Some data are based on the school leaders' information if the law major is one department of the school. There are eighteen universities whose law school deans' information are not available, including Dalian University of Technology, Communication University of China, Beijing Jiaotong University, Beijing Forestry University, Beijing University of Chinese Medicine, East China Normal University, Liaoning University, Northeast Agricultural University, Hohai University, Nanjing University of

50. The Chinese Communist Party. 
Aeronautics and Astronautics, Nanjing University of Science and Technology, Central China Normal University, Wuhan University of Technology, South China Normal University, Xinjiang University, Shihezi University, the National University of Defense Technology, and Shanxi Normal University. Five of the law schools' websites are not accessible, including Shanghai International Studies University, East China University Of Science and Technology, Inner Mongolia University, Guangxi University, and Tibet University. There are eleven universities without law schools or law majors, including Central Conservatory of Music, Beijing Sport University, Tianjin Medical University, University of Science and Technology of China, Hefei University of Technology, China University Of Petroleum (Eastern China), Xi'an Electronic and Engineering University, Qinghai University, The Second Military Medical University, The Fourth Military Medical University, and China Pharmaceutical University.

From the above statistics, we can see that women are a small percentage of law school dean-level administrators; in fact at these eighty-four schools they are only 22.25 percent of dean-level administrators. Only six of the law schools had 50 percent or more female dean-level administrators. Even in law schools where more women participate in administration than men, generally the total number of women is still small and female law school deans remain quite rare.

Currently, the leaders in many Chinese law schools are selected through the combination of a number of methods: self-volunteering, being recommended by a superior organization, open competition, and democratic elections. However, it is still difficult for a woman to be promoted in the male-dominated law schools.

That men are higher than women and women should be managed by men are the models accepted by the social cultures. "If their superior is a woman, they would feel uncomfortable. From a man's perspective, being led by a woman leader is a humiliation. Also, if a woman becomes a leader, it will normally be alienated from the general women. Generally, the able female persons are a bit strange: they don't have the sensation of women, don't need family and don't need ordinary life. When a woman is very successful (or takes the most important position), others may feel strange. They can't help thinking that this woman probably has some "extraordinary" abilities or has sexual relationship[s] with certain male superiors." 51

The traditional culture believes that females' characteristics such as acting impetuously, being cautious and meticulous, and tenderness are

51. Comment by a male law faculty member. 
not suitable for being managers. What managers need is masculinities, such as decisiveness, being rational and courageous, which are being lacked by females.

In the interview, some male law faculty members commented: "There are inherent differences between the interest and capacity structures between men and women. Men should do what men are born to do, while women should do what they are born to do. Thus, men should be leaders and women should do some more meticulous work. I support women to work, but women should focus on home work, and men should be career oriented. Of course I do not object that extraordinary women become leaders, who may do a better work than men, but in general, men are more suitable to be in the leadership positions."

\section{D. "The Other" in Legal Education}

In other countries, scholars have conducted significant research on women in legal education. For example, in Australia, Margaret Thornton has interviewed law school students, scholars, lawyers, judges, and others in various states. She recorded and transcribed more than one hundred interviews. ${ }^{52}$ Thornton has inspected females' experiences and feelings in law schools and law careers, including the reasons why they chose law, the treatment they received in law schools, their classroom experiences, and how they structured knowledge they received from law schools. She ultimately came to the conclusion that females were still in the status of "the other." 33

One of the important reasons that women are still "the other" in law schools is the myth about a conflict between legal characteristics and feminine characteristics. Affected by biological determinism and traditional jurisprudence, the characteristics supposedly possessed by law, such as being rational, objective, neutral, and stable, are considered to conform with masculinity; on the other hand, the so-called female characteristics, such as being irrational, sensitive, fickle, and subjective, are considered to be in conflict with the characteristics of law. ${ }^{54}$ As a result, women's psychological characteristics and ways of thinking are considered not suitable for the study of law.

52. Margaret Thornton, Dissonance and Distrust: Women in the Legal Profession 6-7 (Xin Chunying \&Wang Li, trans., 2001) (1996).

53. See id. (discussing Margaret Thornton's research and interviews, as well as her conclusion that women "have not been fully accepted as citizens of the jurisprudential community").

54. See Frances E. Olsen, Feminism and Critical Legal Theory: An American Perspective, in FEMINIST LEGAL THEORY I 473, 475 (Frances E. Olsen ed., 1995). 
In my survey, I asked the question: "In your opinion, generally speaking, do male students or female students have better grades in law schools?" Among respondents, 65.4 percent of law faculty responded that females have better grades, 12.5 percent said males have, and 19.2 percent declined to make a comparison. Among the student respondents, 51.1 percent considered that female students study better than their male classmates, only 14.8 percent thought male students study better, and the remaining 32.8 percent declined to make a comparison. I also asked the question: "As between male and female students, who prefers to speak up in classes?" Of student respondents, 27.2 percent thought male students speak more, 25.8 percent thought female students speak more, 24.6 percent thought they speak with the same frequency, and the remaining 21.6 percent said they paid no attention to this issue.

In China, even though female students win most of the scholarships, it is not true that females have achieved success and shed their status as "others." The unfair treatment received by female students in the recruitment for postgraduate students can explain this. In addition, female students' better grades have failed to win them the recognition of professors and fellow students with respect to their ability to study law. A majority of interviewees thought male students are able to learn and grasp law better than female students.

In response to the question: "According to your opinion, who is better suited to study law, male students or female students?" 39.8 percent of student respondents said male students are better suited. Only 11.7 percent of students thought female students were better suited to law studies, while the remaining 47.8 percent of students declined to make a comparison. 58.6 percent of male respondents said male students are better suited and 29.7 percent of female respondents said so. 17.1 percent of female respondents and $5.2 \%$ of male respondents think women are more suitable for studying law. 36.2 percent of men and 57.9 percent of women think it is unable to compare. Thus, male respondents tend to think that men are more suitable for studying law; female respondents tend to think that they are unable to compare men or women regarding who is more suitable for studying law. However, even female respondents who think women are more suitable for learning law make up less than 20 percent, while nearly 60 percent of male respondents think that men are more suitable for studying law. Among graduate students, more respondents believe that men are more suitable for studying law. 53.1 percent of graduate students responded that men were better suited.

Among law faculty, 49 percent of respondents believed that there is no difference in the ability for studying law between men and women. 
There are 37.7 percent of male respondents who believed that there is no difference between men and women, and 60.8 percent of female respondents believed there was no difference. 51 percent of respondents believed that men and women differ in their capability to study law. Among them, there were 62.3 percent male respondents and 37.3 percent female respondents who believe that men were better suited than women. According to the questionnaire, the main reason for this conclusion is a belief that males are more logical and rational than females.

The above questionnaires and interviews I conducted show that the female students are widely believed to be emotional and lacking in critical thinking skills and logic, but rational thinking is considered an essential skill to study law. For example,

Just talk[ing] about academic records, sure, women are better. However, women only read books and know little about practice. In contrast, as I know, many men's academic performance may be not that excellent, but they have unique ideas and wide-ranging knowledge and know how to solve practical problems. At this point, I think men are better than women.

\section{-Law school male undergraduate}

Women lack the capabilities to think and analyze; there have been few women philosophers in the world. There's no discrimination against women if women are actually weaker in abstract thinking than men. Females always focus on reality, so they have better practical skill in different kinds of laws, but on the abstract level they often encounter bottlenecks. ... Women may have better scores in exams because exams require less thinking, analyzing and abstract thought, but law requires legal philosophy, and women have problems with "why," so they cannot reach that far. Actually, this opinion is a little biased, but the data shows us it is true, even there are some of the brilliant philosophers.

\section{-Law school second-year male undergraduate}

Since some interviewees believed that women are less capable of studying law than men, how did they explain that females have better law school grades? 


\section{a. Women are more hard-working}

Law is not an interesting subject, and women are more willing to sit and study while men are bored with that. Most men are capable of studying well but not willing to spend time on studying. The fact that the best grades in the class go to men proves it.

-Law school male undergraduate

Women study much harder, they spend the most time in the classroom, but in my opinion: no pain, no gain.

-Law school female undergraduate

[Women are] much more hard working, it could be that they use the time men spend playing ball and drinking, to study.

-Civil and economical law school female undergraduate

In school, women like to study, have better grades, and take active part in various activities. Maybe this is because they have more problems in finding a job and have more sense of crisis.

-Law school female undergraduate

b. Women have better memories

[Women] have better memories than men.

-Civil and economical law school female undergraduate

Laws are conventions and regulations; women are the ones who can memorize them, so naturally they have better grades.

-Law school third-year female undergraduate 
c. The exam methods favor female students

From my point of view, law school education is more exam-oriented education, and women are more willing to spend time in coping with exams, women can easily memorize information. But as to practice, men have better staying power and adaptability.

-Law school male undergraduate

It is the exam criteria that disfavor men. Our scores basically depend on the final exam paper, even the regular grade are mostly the same. This kind of test form favors the women who have better memory skills, and men cannot show their advantages.

-Law school male undergraduate

Men love to play, such as games, especially when law study is boring and theoretical. Male students can hardly focus on course study while the exam is mainly about books. Female students are better behaved and study long after class. Females are skilled in exam taking, and girls have great word processing capability, while exam[s] consist mainly of brief answers and discussion; for those reasons, women will answer more properly.

-Law school female undergraduate

Legal education has problems, nowadays we study only for exams. . . The point is some women with great scores know nothing but memorize, men do not study well but could learn slowly in practice, even though they may not learn from books.

-Law school male undergraduate

From the above interview we can see, in addition to being affected by biological determinism and gender essentialism, the hierarchy in dualism is also an obstacle for women in the legal field. The dualisms do not just divide the world between two terms; the two terms are arranged in a hierarchical order. Just as men dominate and define 
women, one side of the dualism dominates and defines the other. Irrational is the absence of rational; passive is the failure of active; thought is more important than feeling; reason takes precedence over emotion. ${ }^{55}$

This dualism hierarchy has caused underappreciation of the capability of female law students to learn and practice law, even though their performances in school are considered better than male students by most interviewees. Better performance and the higher number of female students are habitually attributed to flawed exam methods, ${ }^{56}$ better memories and writing skills, or diligence on the part of female students. Although diligence, good memory, and writing ability are regarded as the female strengths, these advantages are considered not worth mentioning, as they are valued much lower than the rational thinking and practical ability, which the interviewees believe men have or should have.

Some law faculties also have biased views about gender. In response to the question: "Is any discriminatory language used by professors in their lectures?" 52 percent of student respondents said yes. Almost half of the students thought that some professors have double standards for female and male students and that professors' impressions of female and male students are rigid, which results in differing languages, attitudes, and expectations being expressed towards male and female students. For example, 35.5 percent of students said some professors expressed the view that male students have stronger logic and analytical abilities and are better suited to major in law.

The phenomenon of professors having different attitudes and expectations towards male students and female students based on their rigid expectations of the sexes is common. On one occasion, when I was attending the pre-answering for a masters' thesis, I heard a male professor express his deep surprise and concern about a female student choosing Judge Posner's theory as the topic for her paper; he feared that the girl would not be able handle it. Another male professor commented on a female student's thesis and said that "female students need to be

55. Id. at 474 .

56. The former dean of Shanghai Academy of Social Sciences and president of Shanghai Education and Development Foundation, Wang Ronghua, asserted that 'boys' crisis" shows there are some problems with the educational system, examination system and evaluation criteria on developing boys' enthusiasm and advantages. Zhang Ling \& Zhang Xiaoge (张灵 \& 张晓鸽), HUI FU NAN XIAO N口 XIAO YIN RE YI, YIN XING SHI JIAO SHI FOU DA SHI SUO QU (惞复男校女校引热议, 因性施教是否大势所趋) [The Regain of All-Boys School and All-Girls School Caused Heated Discussion, Whether It Is the Trend to Educate by Gender?], JING HUA SHI BAO (京华时报) [BEIJING TIMES], Apr. 24, 2012, at http://news.xinhuanet.com /edu/2012-04/24/c_111830042.htm. 
more rigorous in their papers because the problem of lack of rigor is more serious for females."

In the interviews, some students expressed similar opinions:

Once I consulted a professor about a program for studying in Germany, which was highly recommended by him in class, but when I asked, he was eager to tell me that women should not apply to Ph.D programs, which are not necessary for them. I was stupefied.

\section{-Junior female}

When I attended an exchange program selection procedure, teachers chose a male to represent our school because of gender even though the girls are much more brilliant. . . I I think in a college with more women than men that men will get better treatment whenever searching jobs or evaluating excellent students. In the same way many male senior interns found great jobs despite being less qualified while a lot of senior female interns could not get positions even though they were much more qualified than the men.

\section{-Junior female}

I remember in one of my courses the professor told us that law was one of the most difficult careers and was more suitable to men than women. He suggested that women should not choose law as a career. His comment has a discriminatory meaning even if he intended to show consideration for female students. I felt uncomfortable that he was saying women could not compare with men.

\section{-Junior female}

Our professor told us that women choosing economic law were a deviation from the role of women; he even said that if women enjoyed researching in this area it was a deviation. 
Regarding the different directions and suggestions that teachers give students based on gender, some students expressed their understanding as follows:

This is not unfair, because professors teach students in accordance with their aptitudes; professors definitely shall give different suggestions depending on the students' characters; this is understandable.

\section{-Undergraduate female}

Until now, the legal culture and concept that women are a "dangerous force which is harmful to rationality" has not been completely eliminated, and women have not been accepted as "true legal practitioners." 57 When women enter a traditionally male-dominated field traditionally, many people perceive this as abnormal, feel nervous about the change, and want to stop it. Such people think that "too many" female students at law school are harmful, and the greater number of female students has been considered one of three problems in legal education. ${ }^{58}$ As a result, the law schools and professors gave male students priority in enrollment. But in the schools of science and engineering, which enroll fewer women, nobody thinks that the exam and education system's flaws cause are the cause of lower female enrollment; rather it is believed that females are not good at these fields so schools prefer not to give females priority.

In fact, "law is not now, and could not, consistent with what we believe, become principled, rational, and objective." 59 "The law itself is only a set of interpersonal cooperation rules. Legal theory established on the basis of law is just a kind of explanation."60 Moreover, women are not inevitably irrational and subjective just as men are not necessarily rational and objective. Although women have entered legal education in large numbers, the gender stereotypes remain common, handicapping

57. Wang Jingyi (王静怡), FA Lò ZHI YE ZHONG DE XING BIE PIAN JIAN-PING LÒ ZHENG QIAO JIA REN (法律职业中的性别偏见一一评《律政俏佳人》) [Gender Bias in Legal Profession: Review on Legally Blonde], in YING XIANG ZHONG DE SI FA (影像中的司法) [JUdicature In Motion Pictures] (Xu Xin ed., 2006).

58. Xu Chongli, the dean of Xiamen University School of Law addressed that: "the ratio imbalance between male and female students, lower student's quality, and teachers' practical ability is relatively weak, is currently three problems which China's legal education are facing." Li Tiezhu, supra note 27.

59. Olsen, supra note 54, at 482 .

60. Zhou Anping (周安平), FA XUE YU KE XUE JI LUO JI DE JIU CHAN YU ZHEN BIE (法学与科学及逻辑的纠细与甄别) [Entanglement and Identification among Jurisprudence, Science and Logic], 8 JIANG XI SOCIAL SCIENCES. 194 (2008). 
the development of women in this field. The constraints imposed by dualism and gender essentialism-i.e. to attribute certain features to "masculinity," and the other characters to "femininity," and to consider these qualities as being formed naturally-must be broken, but this will not be easy in China.

\section{BEHIND THE SEX-DisCRIMINATION AND PREJUdiCe IN LEGAL EDUCATION}

The traditional culture and epistemology cause the sex-discrimination and prejudice in legal education, as well as in other fields.

\section{A. The Dualisms in Chinese Traditional Culture}

In Chinese traditional culture, everything in existence has a dual nature comprised of yin and yang. The existence of the universe and the changes in it are the result of the mutual interaction between yin and yang. Although traditional Chinese culture emphasizes harmony and balance between heaven and earth, the ancient Chinese theory of yin and yang is also a typical dualism. For example, Zhou Yi, one of the classic ancient Chinese books of philosophy, uses Qian and Kun, consisting of ". " and ". ." to represent the two opposing ends. Qian symbolizes yang, heaven, men, and superiority. Kun symbolizes yin, earth, women, and vassals. The world view of the ancient Chinese is based on the dualism of yin and yang, which corresponds to Qian and Kun, heaven and earth, men and women, gain and loss, and good and bad. 61

Chinese yin and yang theory also has characteristics similar to the western traditional dualism, which Professor Olsen summarized as follows: 62

(a) Sexualization: According to the Chinese theory of yin and yang, everything in the world should be divided into yin and yang essentially. And men and women, husband and wife is the most basic sector from the perspective of dualism. Furthermore, as the incarnation of the male, yang often is linked with to such characteristics as the bright, energetic, positive, whereas yin representing

61. XIE YU'E, Investigating the Roots of Classical Chinese of Gender Discourse, in FEMINISM IN ChINA 41 (Huang Lin, ed. 2004).

62. See Olsen, supra note 54, at 473-75. 
women is always linked with to those dark, smooth, negative features. As Ban Zhao wrote in "The Preach to Women," "Yin and yang are different, and so are men and women. It is the most important for yang to be powerful, and for yin to be delicate. Accordingly, men should be strong and women."63 It embodies the characteristics of gendering of Chinese yin and yang theory.

(b) Hierachization. The status of yin and yang, as the two ends of the dualism, is defined by "Yi Zhuan": "The heaven is noble and the earth is humble."64 Especially, with the development of the Confucianism, the idea on lowliness and nobleness in the theory of yin and yang was strengthened. As the linkage with the theory of yin and yang, the gender hierarchy was formed and it became the theoretical base of the traditional ethics of "the think that women are inferior to men" and "Wifely Submissions and Virtues."

(c) Law as male. Different from western theory, law are never as important and respectable as $l i$ in China. However, the activities the male and female engaged in are divided into two areas: the outer and the inner, the public and the private. "The outside," "public affairs" is a man's territory, and "the inside," "private business" is a female space. This division is given significance of "the fundamental principle between the heaven and the earth." Law naturally belongs to the "outside" and "public" domain, so it is exclusive to the men and is cut off from the women. It is remarkably similar to the western ideology that society activities are divided into public and private spheres and women were excluded from the public including legal affairs.

Although the Chinese theory of yin and yang is a dualism embodying the above three characteristics similar to some characteristics of Western philosophy, we should notice some differences between traditional Chinese and modern Western thinking. The modern

63. LI YINHE (李银河), THE FEMINISM DEBATE OVER GENDER TEMPERAMENT (女权主义围绕性别气质问题的论争), in HUANG LIN \& WANG HONGQI (荒林、王红旗), ZHONG GUO N $\square$ XING WEN HUA (中国女性文化) [CHINESE FEMALE CULTURE] 18 (2001).

64. XIE, supra note 61. 
Western worldview generally regards the relationship of opposites as a hostile relationship with conflicting interests, while in the ancient Chinese theory of yin-yang there is less rivalry and competition between the opposites, and more emphasis is put on harmony and unity, and complementarity and interdependence. ${ }^{65}$

The harmony between male and female is always emphasized; however, there is still definite discrimination between the sexes. Harmony between yin and yang is not a synonym for gender equality. At the same time, the concepts of harmonization and complement in the traditional Chinese theory of yin and yang are quite different from an antiessentialism, ${ }^{66}$ anticenter doctrine, or an abandonment of binary opposition found in postmodern feminist jurisprudence. Although Chinese yin-yang theory deemphasizes the patterns of confrontation and competition between the sexes, and emphasizes their harmonious and complementary characteristics, it is still a form of hierarchical dualism, and contains a strong element of essentialism.

According to Professor Li Yinhe, because such concepts as the balance and the complement of yin and yang are deeply rooted, it is not easy for the Chinese to rid themselves of gender essentialism, However, postmodern feminism and antiessentialism are quite subversive because they fundamentally denied the so-called dichotomy of male and female. Therefore, the Chinese, who sincerely believe in the yin-yang dichotomy, find it even more difficult to accept a postmodern feminist antiessentialist position than do those Westerners who maintain a viewpoint of sexual binary opposition. 67

In recent years, traditional Chinese culture, including traditional gender concepts and attitudes, has been revived to some extent. For example, according to the Third Wave Survey on the Social Status of Women in China in 2010, 61.6 percent of men and 54.6 percent of women agree that "the male domain is in public and the female domain is within household," which represents increases of 7.7 percent and 4.4 percent, respectively, as compared to the year 2000.68

65. LI YINHE, supra note 63 , at 23.

66. Antiessentialism is the opposite of essentialism. Essentialism has been defined as: "the set of fundamental attributes which are necessary and sufficient conditions for a thing to be [considered] a thing of that type." M.A. Ntumy, Essentialism and the Search for the Essence of Law, 18 MELANESIAN L.J. 64, 64 (1990).

67. LI YINHE, supra note 63, at 23.

68. "The Third Wave Survey on the Social Status of Women in China jointly launched and organized by the All-China Women's Federation (ACWF) and National Bureau of Statistics (NBS), is a nationwide decennial survey following the first and second wave surveys conducted respectively in 1990 and 2000 . The third wave survey, [was] carried out on December 1, 2010.” ALL-CHINA WOMEN'S FED'N, REPOR'T ON MAJOR RESUlTS OF THE 


\section{B. Beyond the Legal Education}

Women law students are not the only ones facing gender bias. In July 2012, a group of public interest lawyers applied to the Ministry of Education to release information about gender differences in the minimum score required on the National Higher Education Entrance Examination $^{69}$ for admission to university. For example, in 2012, various departments at Shanghai International Studies University required women to score about thirty to forty points higher than men in order to win admission, and in Tianjin, the minimum admission scores for women were fifty-eight points higher than those for men. ${ }^{70}$ The Ministry of Education issued a reply on October 15, 2012, listing three kinds of university majors in which colleges and universities are allowed to restrict the gender ratio of enrolled students. These kinds of majors are: 1) the majors that are closely related to the needs of specific professions, which themselves require the certain gender ratio-such as the military, national defense forces, and public security; 2) majors that appropriately restrict the number of women for the purpose of protecting them-such as navigation and mining; and 3) majors that have limited educational resources and thus can admit only limited numbers of students, but a certain gender balance is necessary to meet social demand, including some non-Universal Language, broadcasting, and hosting art, and so on. In such instances, the ministry argued that failure to maintain a certain gender ratio in admissions could give rise a serious imbalance between male and female graduates and would materially affect educational outcomes and social productivity, and in some cases also affect the ability of universities to meet the hiring needs of government departments. ${ }^{71}$

From the reply of the Ministry of Education, we can see that women still need to be "protected," and they are not acknowledged to have the capability to decide their own learning objectives. Those majors dominated by men, such as mechanical, electronical, and civil engineering, never lower admission scores for women because people believe women are not good at these subjects. When women dominate majors such as less-commonly studied languages, restrictions must be

Third Wave SURVey on the Social STATUS OF WOMEN IN CHINA (2011), available at http://www.womenwatch-china.org/en/newsdetail.aspx?id=5176.

69. Huo Li, The Ministry of Education Responded the Sex "Discrimination" in THE National Higher EduCATION ENTRANCE EXAMINATION: Without Limiting THE GENDER RATIO WILL AFFECT THE EDUCATIONAL EFFECT (Oct. 17, 2012), available at http://politics.caijing.com.cn /2012-10-17/112202824.html.

70. $I d$.

71. Id. 
set on the number of women admitted, otherwise there will be a waste of educational resources that will negatively impact "educational outcomes and social productivity"72 and hurt the interests of government departments that recruit from university departments where gender imbalances exist.

The achievements of women in school have also triggered a debate and much concern about a "boy crisis." The boy crisis refers to phenomenon that boys are behind girls in the study, physique, mind, and social adaptation ability, and so on. In response to the so-called "boy crisis," in addition to setting up a quota system for men in universities, the solution of gender-segregated education has been resurrected.

In 2012, the Shanghai Municipal Education Committee approved establishment of a "Shanghai all-boys high school experimental class" at Shanghai No.8 High School. ${ }^{73}$ The principal of the Shanghai No.8 Middle School, Lu Qisheng, said that the all-boys school aims at dealing with the "boy crisis," in order to solve the problem of boys being feminized and overshadowed by girls. ${ }^{74} \mathrm{Lu}$ Qisheng said that the aim of No. 8 Middle School is mainly to "make the best use of the advantages and bypass the disadvantages" to develop boys' special talents and potentials as much as possible. ${ }^{75}$ The all-boys class will try to set up some different courses, such as wilderness survival use of electric tools, and electric appliance repair. Boxing, chess, and electric music are also featured. ${ }^{76}$

At the same time, all-girls schools ${ }^{77}$ in China also feature gender-role reinforcing course selections. Elective courses at the Beijing Huaxia Girls School include wind music, the art of tea, the art of communication, DIY decoration, and minority dancing. ${ }^{78}$ In Wuxi No.1 Girls School, students are required to take courses on etiquette and physique, and the school has criteria on sitting, standing, and walking. ${ }^{79}$ The Shanghai No.3 Girls School holds an annual "IACE Girl"

72. Id.

73. Ling \& Xiaoge, supra note 56.

74. Id.

75. $I d$.

76. Id.

77. At present there are five all-girls middle schools in China: Beijing Huaxia Girls School, Shanghai No.3 Girls School, Wuxi No.1 Girls School, Zhuhai Girls School, and Zhenzhou Girls High School. The dean and special-grade teacher of Beijing Huaxia Girls School, Song Liqin, stated "Recently, we have been receiving delegations from outside of the city and province, and a number of districts are planning on re-establishing all-girls schools. For example, Tianjin No.11 Middle School has already tried to set up an all-girls class and is preparing on re-establishing all-girls school." Ling \& Xiaoge, supra note 56.

78. $I d$.

79. Id. 
competition to select a female student who embodies independence, ability, care, and elegance. ${ }^{80}$

Chinese educators us an expression: "yin cai shi jiao," which means "teach students according to their aptitude." Nowadays, this has more and more been understood as: "teach students according to their gender" and become a rapid spreading and universal panacea for boy crisis. ${ }^{81}$ Each individual student is different from others, and when teaching according to student aptitudes is tied to the students' gender, the result is that all students are actually taught in accordance with their gender, not their aptitude. Education based on such gender stereotypes will only strengthen the gender discrimination throughout society.

80. Id.

81. Xu Anqi, Boy Crisis: An Alarmist False Dichotomy, 1 YouTH STUD. 44 (2010). 
APPENDIX:82

\begin{tabular}{|c|c|c|c|c|}
\hline Law School & Total & Female & $\begin{array}{c}\text { Percentage } \\
\text { that are } \\
\text { female }\end{array}$ & Female's position \\
\hline $\begin{array}{l}\text { Peking University } \\
\text { Law School }\end{array}$ & 8 & 1 & $12.5 \%$ & $\begin{array}{l}\text { Deputy Secretary } \\
\text { of the CCP }\end{array}$ \\
\hline $\begin{array}{l}\text { Tsinghua University } \\
\text { School of Law }\end{array}$ & 7 & 1 & $14.3 \%$ & $\begin{array}{l}\text { Deputy Secretary } \\
\text { of the CCP }\end{array}$ \\
\hline $\begin{array}{l}\text { Fudan University } \\
\text { School of Law }\end{array}$ & 6 & 2 & $33.3 \%$ & $\begin{array}{l}\text { Deputy Secretary } \\
\text { of the CCP, } \\
\text { Deputy Dean }\end{array}$ \\
\hline $\begin{array}{l}\text { Koguan Law School } \\
\text { of Shanghai } \\
\text { Jiaotong University }\end{array}$ & 6 & 1 & $16.7 \%$ & $\begin{array}{l}\text { Deputy Secretary } \\
\text { of the CCP }\end{array}$ \\
\hline $\begin{array}{l}\text { Jilin University } \\
\text { School of Law }\end{array}$ & 8 & 3 & $37.5 \%$ & $\begin{array}{l}\text { Deputy Secretary } \\
\text { of the CCP, } \\
\text { Deputy Dean }\end{array}$ \\
\hline $\begin{array}{l}\text { Northeastern } \\
\text { University } \\
\text { School of } \\
\text { Humanities and } \\
\text { Law }\end{array}$ & 7 & 1 & $14.3 \%$ & Deputy Dean \\
\hline $\begin{array}{l}\text { Law and Politics } \\
\text { School of Ocean } \\
\text { University of China }\end{array}$ & 5 & 2 & $40 \%$ & $\begin{array}{l}\text { Deputy Secretary } \\
\text { of the CCP, } \\
\text { Deputy Dean }\end{array}$ \\
\hline $\begin{array}{l}\text { School of Law, } \\
\text { Southeast } \\
\text { University }\end{array}$ & 5 & 1 & $20 \%$ & $\begin{array}{l}\text { Chief Secretary of } \\
\text { the CCP }\end{array}$ \\
\hline $\begin{array}{l}\text { School of Law, } \\
\text { Xiamen University }\end{array}$ & 7 & 4 & $57.1 \%$ & $\begin{array}{l}\text { Deputy Secretary } \\
\text { of the CCP, } \\
\text { Deputy Deans }\end{array}$ \\
\hline $\begin{array}{l}\text { School of Law of } \\
\text { Sun Yat-sen } \\
\text { University }\end{array}$ & 6 & 3 & $50 \%$ & $\begin{array}{l}\text { Deputy Secretary } \\
\text { of the CCP, } \\
\text { Deputy Dean }\end{array}$ \\
\hline $\begin{array}{l}\text { School of Law of } \\
\text { South China } \\
\text { University of } \\
\text { Technology }\end{array}$ & 5 & 2 & $40 \%$ & $\begin{array}{l}\text { Deputy Secretary } \\
\text { of the CCP, } \\
\text { Deputy Dean }\end{array}$ \\
\hline
\end{tabular}

82. The data for Jilin University School of Law, Ximen University School of Law, and Minzu University Law School was collected from their websites in March 2013. Other data was collected from these law schools' websites in November 2012. 


\begin{tabular}{|c|c|c|c|c|}
\hline $\begin{array}{l}\text { School of Law } \\
\text { Central South } \\
\text { University } \\
\end{array}$ & 6 & 0 & $0 \%$ & none \\
\hline $\begin{array}{l}\text { School of Law } \\
\text { Hunan University }\end{array}$ & 7 & 1 & $14.3 \%$ & $\begin{array}{l}\text { Deputy Secretary } \\
\text { of the CCP }\end{array}$ \\
\hline $\begin{array}{l}\text { Wuhan University } \\
\text { School of Law }\end{array}$ & 8 & 2 & $25 \%$ & $\begin{array}{l}\text { Deputy Secretary } \\
\text { of the CCP }\end{array}$ \\
\hline $\begin{array}{l}\text { School of } \\
\text { Humanities and } \\
\text { Social Science } \\
\text { Beijing Institute of } \\
\text { Technology }\end{array}$ & 7 & 2 & $28.6 \%$ & Deputy Dean \\
\hline $\begin{array}{l}\text { Renmin University } \\
\text { of China Law School }\end{array}$ & 8 & 1 & $12.5 \%$ & $\begin{array}{l}\text { Chief Secretary of } \\
\text { the CCP }\end{array}$ \\
\hline $\begin{array}{l}\text { Law School, Beijing } \\
\text { Normal University }\end{array}$ & 6 & 2 & $33.3 \%$ & Deputy Dean \\
\hline $\begin{array}{l}\text { Lanzhou University } \\
\text { Law School }\end{array}$ & 7 & 1 & $14.3 \%$ & $\begin{array}{l}\text { Deputy Secretary } \\
\text { of the CCP }\end{array}$ \\
\hline $\begin{array}{l}\text { Law School of } \\
\text { Sichuan University }\end{array}$ & 5 & 0 & $0 \%$ & none \\
\hline $\begin{array}{l}\text { University of } \\
\text { Electronic Science } \\
\text { and Technology } \\
\text { School of Political } \\
\text { Science and Public } \\
\text { Administration }\end{array}$ & 5 & 0 & $0 \%$ & none \\
\hline $\begin{array}{l}\text { School of Law } \\
\text { Chongqing } \\
\text { University }\end{array}$ & 6 & 1 & $16.7 \%$ & $\begin{array}{l}\text { Deputy Secretary } \\
\text { of the CCP }\end{array}$ \\
\hline $\begin{array}{l}\text { College of } \\
\text { Humanities and } \\
\text { Development } \\
\text { Studies China } \\
\text { Agricultural } \\
\text { University } \\
\end{array}$ & 6 & 2 & $33.3 \%$ & $\begin{array}{l}\text { Deputy Secretary } \\
\text { of the CCP, } \\
\text { Deputy Dean }\end{array}$ \\
\hline $\begin{array}{l}\text { Law School, Minzu } \\
\text { University of China }\end{array}$ & 5 & 3 & $60 \%$ & $\begin{array}{l}\text { Deputy Secretary } \\
\text { of the CCP, } \\
\text { Deputy Dean }\end{array}$ \\
\hline $\begin{array}{l}\text { Humanities School } \\
\text { Northwest A\&F } \\
\text { University }\end{array}$ & 5 & 0 & $0 \%$ & none \\
\hline $\begin{array}{l}\text { Shanghai } \\
\text { University Law }\end{array}$ & 6 & 1 & $16.7 \%$ & Deputy Dean \\
\hline
\end{tabular}




\begin{tabular}{|c|c|c|c|c|}
\hline School & & & & \\
\hline $\begin{array}{l}\text { Nanjing Normal } \\
\text { University Law } \\
\text { School } \\
\end{array}$ & 7 & 0 & $0 \%$ & none \\
\hline $\begin{array}{l}\text { Xi'an Jiaotong } \\
\text { University School of } \\
\text { Law }\end{array}$ & 5 & 0 & $0 \%$ & none \\
\hline $\begin{array}{l}\text { Zhejiang University } \\
\text { Guanghua Law } \\
\text { School }\end{array}$ & 7 & 1 & $14.3 \%$ & $\begin{array}{l}\text { Deputy Secretary } \\
\text { of the CCP }\end{array}$ \\
\hline $\begin{array}{l}\text { Beijing University of } \\
\text { TEchnology } \\
\text { Humanities and } \\
\text { Social Science } \\
\end{array}$ & 6 & 2 & $33.3 \%$ & $\begin{array}{l}\text { Chief Secretary of } \\
\text { the CCP, Deputy } \\
\text { Secretary of the } \\
\text { CCP }\end{array}$ \\
\hline $\begin{array}{l}\text { Beijing Institute of } \\
\text { Technology School of } \\
\text { Law }\end{array}$ & 5 & 1 & $20 \%$ & Deputy Dean \\
\hline $\begin{array}{l}\text { The Law School of } \\
\text { Beijing University of } \\
\text { Aeronautics and } \\
\text { Astronautics }\end{array}$ & 7 & 2 & $28.6 \%$ & $\begin{array}{l}\text { Chief Secretary of } \\
\text { the CCP ,Deputy } \\
\text { Dean }\end{array}$ \\
\hline $\begin{array}{l}\text { School of Arts and } \\
\text { Law Beijing } \\
\text { University of } \\
\text { Chemical } \\
\text { Technology }\end{array}$ & 6 & 1 & $16.7 \%$ & Deputy Dean \\
\hline $\begin{array}{l}\text { School of } \\
\text { Humanities Beijing } \\
\text { University of Posts } \\
\text { and } \\
\text { Telecommunications }\end{array}$ & 3 & 2 & $66.7 \%$ & $\begin{array}{l}\text { Deputy Secretary } \\
\text { of the CCP, } \\
\text { Deputy Dean }\end{array}$ \\
\hline $\begin{array}{l}\text { School of Law } \\
\text { University of } \\
\text { International } \\
\text { Business and } \\
\text { Economics } \\
\end{array}$ & 6 & 3 & $50 \%$ & $\begin{array}{l}\text { Deputy Secretary } \\
\text { of the CCP, } \\
\text { Deputy Dean }\end{array}$ \\
\hline $\begin{array}{l}\text { School of Law and } \\
\text { Humanities China }\end{array}$ & 6 & 1 & $16.7 \%$ & Dean \\
\hline
\end{tabular}




\begin{tabular}{|c|c|c|c|c|}
\hline \multicolumn{5}{|l|}{$\begin{array}{l}\text { Mining } \\
\text { University(Beijing) }{ }^{83}\end{array}$} \\
\hline $\begin{array}{l}\text { Law School of The } \\
\text { Central University } \\
\text { of Finance and } \\
\text { Economics }\end{array}$ & 4 & 1 & $25 \%$ & $\begin{array}{l}\text { Chief Secretary of } \\
\text { the CCP }\end{array}$ \\
\hline $\begin{array}{l}\text { Beijing Foreign } \\
\text { Studies University } \\
\text { School of Law }\end{array}$ & 3 & 2 & $66.7 \%$ & $\begin{array}{l}\text { Chief Secretary of } \\
\text { the CCP, Deputy } \\
\text { Dean }\end{array}$ \\
\hline $\begin{array}{l}\text { School of } \\
\text { Humanities and } \\
\text { Social Sciences } \\
\text { North China } \\
\text { Electric Power } \\
\text { University) }\end{array}$ & 5 & 0 & $0 \%$ & none \\
\hline Tongji Law School & 4 & 0 & $0 \%$ & none \\
\hline $\begin{array}{l}\text { College of } \\
\text { Humanities } \\
\text { Donghua University }\end{array}$ & 5 & 2 & $40 \%$ & $\begin{array}{l}\text { Deputy Secretary } \\
\text { of the CCP, } \\
\text { Deputy Dean }\end{array}$ \\
\hline $\begin{array}{l}\text { Nankai University } \\
\text { School of Law }\end{array}$ & 5 & 1 & $20 \%$ & $\begin{array}{l}\text { Joint Deputy } \\
\text { Secretary of the } \\
\text { CCP and Deputy } \\
\text { Dean }\end{array}$ \\
\hline $\begin{array}{l}\text { School of Liberal } \\
\text { Arts and Law } \\
\text { Tianjin University }\end{array}$ & 5 & 1 & $20 \%$ & Deputy Dean \\
\hline $\begin{array}{l}\text { Southwestern } \\
\text { University School of } \\
\text { Law }\end{array}$ & 5 & 1 & $20 \%$ & $\begin{array}{l}\text { Joint Chief } \\
\text { Secretary of the } \\
\text { CCP and Deputy } \\
\text { Dean }\end{array}$ \\
\hline $\begin{array}{l}\text { Hebei University of } \\
\text { Technology School of } \\
\text { Humanities and } \\
\text { Law }\end{array}$ & 3 & 1 & $33.3 \%$ & $\begin{array}{l}\text { Chief Secretary of } \\
\text { the CCP }\end{array}$ \\
\hline $\begin{array}{l}\text { College of Political } \\
\text { Science and Law } \\
\text { Taiyuan university } \\
\text { of technology }\end{array}$ & 4 & 2 & $50 \%$ & Deputy Dean \\
\hline College of Political & 7 & 1 & $14.3 \%$ & Deputy Dean \\
\hline
\end{tabular}

83. There are two campuses for China University Of Petroleum, China University of Geosciences, and China Mining University. There is a school of law on each campus, so six law schools are counted. 


\begin{tabular}{|c|c|c|c|c|}
\hline $\begin{array}{l}\text { Science and Law, } \\
\text { The northeast } \\
\text { normal university }\end{array}$ & & & & \\
\hline $\begin{array}{l}\text { Law School Yanbian } \\
\text { University }\end{array}$ & 3 & 1 & $33.3 \%$ & Deputy Dean \\
\hline $\begin{array}{l}\text { College of } \\
\text { Humanities and } \\
\text { Law Northeast } \\
\text { Forestry University }\end{array}$ & 5 & 1 & $20 \%$ & $\begin{array}{l}\text { Joint Deputy } \\
\text { Secretary of the } \\
\text { CCP and Deputy } \\
\text { Dean }\end{array}$ \\
\hline $\begin{array}{l}\text { Law School Dalian } \\
\text { Maritime University }\end{array}$ & 7 & 3 & $42.9 \%$ & $\begin{array}{l}\text { Chief Secretary of } \\
\text { the CCP, Deputy } \\
\text { Secretary of the } \\
\text { CCP, Deputy } \\
\text { Dean }\end{array}$ \\
\hline $\begin{array}{l}\text { Law School Harbin } \\
\text { Institute of } \\
\text { Technology }\end{array}$ & 2 & 0 & $0 \%$ & none \\
\hline $\begin{array}{l}\text { College of } \\
\text { Humanities and } \\
\text { Social Science } \\
\text { Harbin Engineering } \\
\text { University }\end{array}$ & 4 & 1 & $25 \%$ & Deputy Dean \\
\hline $\begin{array}{l}\text { Nanjing University } \\
\text { Law School }\end{array}$ & 5 & 1 & $20 \%$ & Deputy Dean \\
\hline $\begin{array}{l}\text { Suzhou University } \\
\text { Law School }\end{array}$ & 5 & 0 & $0 \%$ & none \\
\hline $\begin{array}{l}\text { School of Law and } \\
\text { Humanities China } \\
\text { Mining University } \\
\text { (Xuzhou) }\end{array}$ & 6 & 1 & $16.7 \%$ & Dean \\
\hline $\begin{array}{l}\text { Nanjing } \\
\text { Agricultural } \\
\text { University Law } \\
\text { School } \\
\end{array}$ & 5 & 0 & $0 \%$ & none \\
\hline $\begin{array}{l}\text { Jiangnan University } \\
\text { Law School }\end{array}$ & 5 & 0 & $0 \%$ & none \\
\hline $\begin{array}{l}\text { Anhui University } \\
\text { Law School }\end{array}$ & 6 & 3 & $50 \%$ & $\begin{array}{l}\text { Dean, Deputy } \\
\text { Secretary of the } \\
\text { CCP, Deputy } \\
\text { Dean }\end{array}$ \\
\hline $\begin{array}{l}\text { Fuzhou University } \\
\text { School of Law }\end{array}$ & 5 & 1 & $20 \%$ & $\begin{array}{l}\text { Chief Secretary of } \\
\text { the CCP }\end{array}$ \\
\hline
\end{tabular}




\begin{tabular}{|c|c|c|c|c|}
\hline $\begin{array}{l}\text { Law School of } \\
\text { Sandong University }\end{array}$ & 7 & 1 & $14.3 \%$ & Deputy Dean \\
\hline $\begin{array}{l}\text { Law School of } \\
\text { Nanchang } \\
\text { University }\end{array}$ & 4 & 0 & $0 \%$ & none \\
\hline $\begin{array}{l}\text { Law School of } \\
\text { Zhengzhou } \\
\text { University } \\
\end{array}$ & 9 & 1 & $11.1 \%$ & $\begin{array}{l}\text { Deputy Secretary } \\
\text { of the CCP }\end{array}$ \\
\hline $\begin{array}{l}\text { Law School of } \\
\text { Huazhong } \\
\text { University of } \\
\text { Science and } \\
\text { Technology } \\
\end{array}$ & 5 & 1 & $20 \%$ & $\begin{array}{l}\text { Chief Secretary of } \\
\text { the CCP }\end{array}$ \\
\hline $\begin{array}{l}\text { Institute of Public } \\
\text { Administration } \\
\text { China University of } \\
\text { Geosciences } \\
\text { (Wuhan) } \\
\end{array}$ & 3 & 0 & $0 \%$ & none \\
\hline $\begin{array}{l}\text { School of } \\
\text { Humanities and } \\
\text { Economic } \\
\text { Management } \\
\text { China University of } \\
\text { Geosciences } \\
\text { (Beijing) }\end{array}$ & 5 & 2 & $40 \%$ & $\begin{array}{l}\text { Deputy Secretary } \\
\text { of the CCP, } \\
\text { Deputy Dean }\end{array}$ \\
\hline $\begin{array}{l}\text { Zhongnan } \\
\text { University of } \\
\text { Economics and Law } \\
\text { School of Law }\end{array}$ & 8 & 2 & $25 \%$ & Deputy Dean \\
\hline $\begin{array}{l}\text { Hunan Normal } \\
\text { University School of } \\
\text { Law }\end{array}$ & 6 & 2 & $33.3 \%$ & $\begin{array}{l}\text { Deputy Secretary } \\
\text { of the CCP, } \\
\text { Deputy Dean }\end{array}$ \\
\hline $\begin{array}{l}\text { Ji'nan University } \\
\text { School of Law }\end{array}$ & 4 & 1 & $25 \%$ & Deputy Dean \\
\hline $\begin{array}{l}\text { School of Political } \\
\text { Science Southwest } \\
\text { Jiaotong University }\end{array}$ & 6 & 1 & $16.7 \%$ & Deputy Dean \\
\hline $\begin{array}{l}\text { Southwestern } \\
\text { University of } \\
\text { Finance and } \\
\text { Economics Law } \\
\text { School }\end{array}$ & 5 & 2 & $40 \%$ & $\begin{array}{l}\text { Chief Secretary of } \\
\text { the CCP, Deputy } \\
\text { Dean }\end{array}$ \\
\hline College of Literature & 4 & 1 & $25 \%$ & Chief Secretary of \\
\hline
\end{tabular}




\begin{tabular}{|c|c|c|c|c|}
\hline $\begin{array}{l}\text { and Law Sichuan } \\
\text { Agricultural } \\
\text { University }\end{array}$ & & & & the $\mathrm{CCP}$ \\
\hline $\begin{array}{l}\text { Law School Yunnan } \\
\text { University }\end{array}$ & 5 & 0 & $0 \%$ & none \\
\hline $\begin{array}{l}\text { Law School } \\
\text { Northwestern } \\
\text { University } \\
\end{array}$ & 5 & 2 & $40 \%$ & $\begin{array}{l}\text { Dean, Deputy } \\
\text { Dean }\end{array}$ \\
\hline $\begin{array}{l}\text { Law School Guizhou } \\
\text { University }\end{array}$ & 5 & 2 & $40 \%$ & $\begin{array}{l}\text { Dean, Deputy } \\
\text { Dean }\end{array}$ \\
\hline $\begin{array}{l}\text { Northwestern } \\
\text { Polytechnical } \\
\text { University } \\
\text { School of } \\
\text { Humanities and } \\
\text { Law }\end{array}$ & 5 & 1 & $20 \%$ & $\begin{array}{l}\text { Deputy Secretary } \\
\text { of the CCP }\end{array}$ \\
\hline $\begin{array}{l}\text { School of Politics } \\
\text { and Administration } \\
\text { Chang'an University }\end{array}$ & 4 & 0 & $0 \%$ & none \\
\hline $\begin{array}{l}\text { Law School Hannan } \\
\text { University }\end{array}$ & 6 & 1 & $16.7 \%$ & Deputy Dean \\
\hline $\begin{array}{l}\text { Ningxia University } \\
\text { College of Politics } \\
\text { and Law }\end{array}$ & 7 & 1 & $14.3 \%$ & Deputy Dean \\
\hline $\begin{array}{l}\text { China University Of } \\
\text { Petroleum School of } \\
\text { Business } \\
\text { Administration } \\
\text { (Beijing) }\end{array}$ & 4 & 1 & $25 \%$ & $\begin{array}{c}\text { Deputy Secretary } \\
\text { of the CCP }\end{array}$ \\
\hline $\begin{array}{l}\text { Huazhong } \\
\text { Agricultural } \\
\text { University } \\
\text { College of } \\
\text { Humanities and } \\
\text { Law }\end{array}$ & 5 & 0 & $0 \%$ & none \\
\hline $\begin{array}{l}\text { Shanghai } \\
\text { University of } \\
\text { Finance and } \\
\text { Economics Law } \\
\text { School }\end{array}$ & 5 & 2 & $40 \%$ & $\begin{array}{l}\text { Chief Secretary of } \\
\text { the CCP, Deputy } \\
\text { Secretary of the } \\
\text { CCP }\end{array}$ \\
\hline
\end{tabular}




\begin{tabular}{lllll}
\hline $\begin{array}{l}\text { China University of } \\
\text { Political Science and } \\
\text { Law School of Law } 84\end{array}$ & 6 & 1 & $16.7 \%$ & Dean \\
\hline $\begin{array}{l}\text { China University of } \\
\begin{array}{l}\text { Political Science and } \\
\text { Law Economic and }\end{array}\end{array}$ & 6 & 0 & $0 \%$ & none \\
$\begin{array}{l}\text { Commercial Law } \\
\text { School }\end{array}$ & & & \\
\hline $\begin{array}{l}\text { China University of } \\
\text { Political Science and }\end{array}$ & 5 & 1 & $20 \%$ & $\begin{array}{l}\text { Joint Chief } \\
\text { Secretary of the } \\
\text { CCP and Deputy } \\
\text { Dean }\end{array}$ \\
$\begin{array}{l}\text { Law School of } \\
\text { Transnational Law }\end{array}$ & & & $\begin{array}{l}\text { Joint Chief } \\
\text { Secretary of the } \\
\text { CCP and Deputy } \\
\text { Dean }\end{array}$ \\
\hline $\begin{array}{l}\text { China University of } \\
\text { Political Science and }\end{array}$ & 6 & 1 & $16.7 \%$ & \\
$\begin{array}{l}\text { Law College of } \\
\text { Criminal Justice }\end{array}$ & & & & \\
\hline
\end{tabular}

84. Four law schools in China University of Political Science and Law are counted.

85. 118 law schools of "project 211" universities are viewed in this article, in which eighty-four law schools' statistical information are included. 
